\title{
Molecular stages of rapid and uniform neuralization of human embryonic stem cells
}

\author{
R Bajpai ${ }^{1}$, G Coppola ${ }^{2}$, M Kaul ${ }^{1,3}$, M Talantova ${ }^{1}$, F Cimadamore ${ }^{1}$ M Nilbratt ${ }^{1}$, DH Geschwind ${ }^{2}$, SA Lipton ${ }^{1}$ and AV Terskikh ${ }^{\star, 1}$
}

Insights into early human development are fundamental for our understanding of human biology. Efficient differentiation of human embryonic stem cells (hESCs) into neural precursor cells is critical for future cell-based therapies. Here, using defined conditions, we characterized a new method for rapid and uniform differentiation of hESCs into committed neural precursor cells (designated C-NPCs). Dynamic gene expression analysis identified several distinct stages of ESC neuralization and revealed functional modules of coregulated genes and pathways. The first wave of gene expression changes, likely corresponding to the transition through primitive ectoderm, started at day 3, preceding the formation of columnar neuroepithelial rosettes. The second wave started at day 5, coinciding with the formation of rosettes. The majority of C-NPCs were positive for both anterior and posterior markers of developing neuroepithelium. In culture, C-NPCs became electrophysiologically functional neurons; on transplantation into neonatal mouse brains, C-NPCs integrated into the cortex and olfactory bulb, acquiring appropriate neuronal morphologies and markers. Compared to rosette-NPCs, ${ }^{1}$ C-NPCs exhibited limited in vitro expansion capacity and did not express potent oncogenes such as PLAG1 or RSP03. Concordantly, we never detected tumors or excessive neural proliferation after transplantation of C-NPCs into mouse brains. In conclusion, our study provides a framework for future analysis of molecular signaling during ESC neuralization.

Cell Death and Differentiation (2009) 16, 807-825; doi:10.1038/cdd.2009.18; published online 13 March 2009

The understanding of early human development is fundamentally important for successful treatment of various pathological conditions. Human ESCs represent a unique model to study early human development, in particular neurogenesis, in vitro. Additionally, the transplantation of brain-derived human neural precursor cells (NPCs) has been shown to mitigate various neurodegenerative disorders in animal models. ${ }^{2-4}$ Primary human tissue, however, is limiting, and the long-term in vitro expansion of NPCs compromises their multilineage potential as well as their capacity for migration and differentiation after transplantation. ${ }^{5-7}$ Although $\mathrm{ESCs}^{8}$ represent a virtually unlimited source of a variety of human cell types, including neural precursors, ${ }^{9-11}$ multiple obstacles remain for this primary source to be realized. Current protocols for generating NPCs from ESCs rely on the initial formation of heterogeneous embryoid bodies, followed by the isolation of neuroepithelial 'rosettes,' usually via differential enzymatic digestion and subsequent propagation of these cells in culture. ${ }^{9}$ Most protocols use extensive passaging ${ }^{10}$ or require immunoenrichment techniques ${ }^{11}$ to increase the number of neural precursors. Efficient differentiation of ESCs into NPCs has been achieved using high concentrations of BMP inhibitors (e.g., Noggin). ${ }^{12-15}$ Although these conditions may favor some differentiation outcomes (e.g., TH-positive neurons), the diversity of cell fates could also be restricted by such treatment. Conti et al. ${ }^{16}$ reported niche-independent self-renewal of neural stem cells derived from mouse ESCs and primary CNS in the absence of exogenous BMP inhibitors. However, human neural stem cells were not analyzed in sufficient detail in that study. More recently, efficient neuralization of ESCs in defined conditions ${ }^{17}$ was proposed to proceed through a primitive anterior neuroectoderm. ${ }^{18}$ Indeed, van der Kooy and colleagues suggested that mouse ESCs differentiate into a transient population of FGF2-independent primitive neural stem cells, which then spontaneously transit to FGF2-dependent expandable neural stem cells. ${ }^{19}$ Very recently, human neural stem cells (NSCs) isolated from primary rosettes (termed rosette-NSCs) were suggested to have broader developmental potential compared to NSCs amplified in monolayer cultures. ${ }^{1}$

Collectively, these results suggest that primary neuroepithelial cells derived from ESCs are different from their extensively cultured progeny. The much broader developmental potential of these cells mandates a detailed analysis of their molecular makeup as well as various strategies for generating these unique cells. However, only a proportion of ESCs forms rosettes and thus becomes neuralized. Neural rosettes can be mechanically isolated only after 10-12 days of differentiation, precluding a genome-wide analysis of the developmental pathways leading to rosette-NSCs.

\footnotetext{
${ }^{1}$ Neuroscience, Aging, and Stem Cell Research Center, Burnham Institute for Medical Research, 10901 North Torrey Pines Rd, La Jolla, CA 92037, USA; ${ }^{2}$ Program in Neurogenetics, David Geffen School of Medicine, University of California at Los Angeles, 710 Westwood Plaza, Los Angeles, CA 90095, USA and ${ }^{3}$ Infectious and Inflammatory Disease Center, Burnham Institute for Medical Research, 10901 North Torrey Pines Rd, La Jolla, CA 92037, USA

*Corresponding author: AV Terskikh, Neroscience, Aging, and Stem Cell Research Center, Burnham Institute for Medical Research, 10901 North Torrye Pines Road, La Jolla, CA 92037, USA. Tel: + 858795 5299; Fax: + 858795 5298; E-mail: terskikh@burnham.org

Keywords: human embryonic stem cells; uniform neural differentiation; expression/coregulation analysis

Abbreviations: bFGF, basic fibroblast growth factor; BMP, bone morphogenetic protein; C-NPCs, committed neural precursor cells; CNS, central nervous system; EGF, epidermis growth factor; GFAP, glial fibrillary acidic protein; hESC, human embryonic stem cells; mEPSC, miniature excitatory postsynaptic current; SVZ, subventricular zone; WGCNA, weighted gene coexpression network analysis

Received 11.6.08; revised 08.12.08; accepted 13.1.09; Edited by R De Maria; published online 13.3.09
} 
Here we report a comprehensive analysis of both the molecular changes and functional outcomes during rapid and uniform ESC neuralization, which proceeds through the neuroepithelial rosette stage. Our whole-genome analysis of gene expression dynamics during the initial phase of neural commitment of ESCs in defined conditions identified two major waves of gene expression. Interestingly, the first prominent changes in gene expression precede the appearance of columnar neuroepithelia, likely corresponding to the transition through primitive ectoderm. We observed a very low level of TGF $\beta /$ Smad signaling, which explains why exogenous BMP inhibitors such as Noggin are not needed for this protocol. The rapidly neuralized C-NPCs displayed a limited capacity for expansion (five passages) but were capable of differentiation into functional neurons and MBP-producing oligodendrocytes.

\section{Results}

Critical steps for rapid and efficient neuralization of ESCs. For derivation of neural precursors, ESC cultures (Figure 1a) were collected by collagenase-IV treatment 5 days after plating. Cell clusters were allowed to settle, and the supernatant containing floating cells was discarded. The ESC clusters were triturated to dislodge loosely attached cells and reduce cluster size to $50-100$ cells. Reducing the cluster size is critical for efficient neuralization because large a

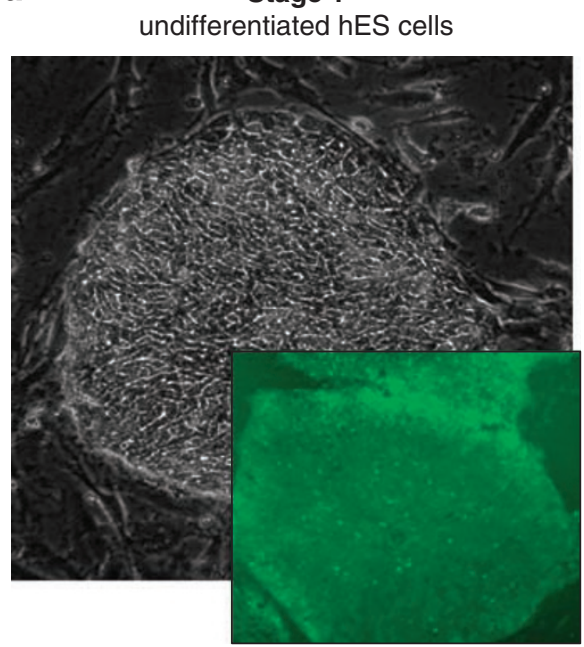

C
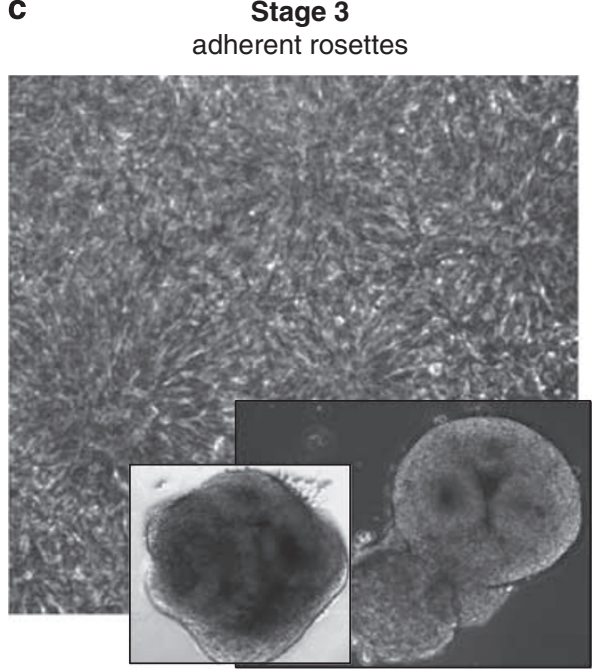

b

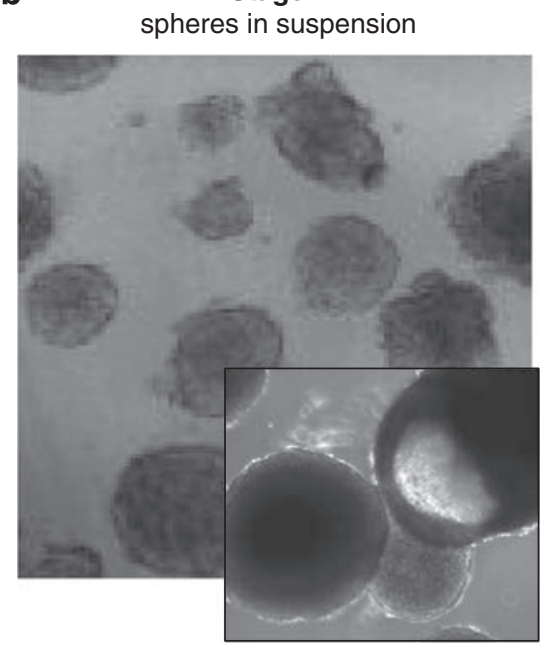

d

Stage 4

hNPCs culture

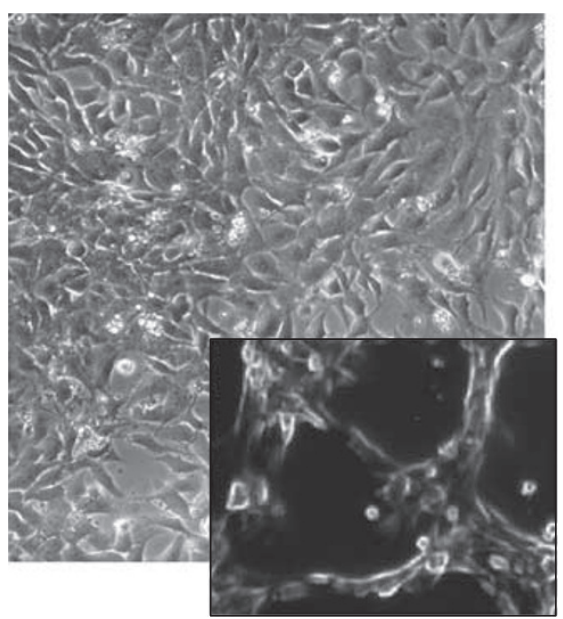

Figure 1 Schematic representation of C-NPC derivation process. (a) Stage 1: colonies of undifferentiated human ESCs (H9 line). Pristine ESC cultures are critical for this protocol. To monitor the quality of ESC culture conditions, we used a separate ESC line engineered to express an eGFP reporter under the control of the Oct4 promoter, a known marker of pluripotent ESCs (inset). (b) Stage 2: compact spheres appeared within 6 days of dissociation with collagenase IV and after repeated washes with PBS. Particular care was taken to avoid large clumps that invariably resulted in spheroid bodies with cavities and layers (inset). (c) Stage 3: spheres transferred to expansion medium formed attached rosettes and cells radiating out of clusters; some floating spheres were composed entirely of rosettes (inset). (d) Stage 4: after an additional 4-6 days ( 10-12 days from the beginning of the differentiation protocol), stage 3 cells were collected in $\mathrm{Ca}^{2+} / \mathrm{Mg}^{2+}$-free PBS, triturated to single cells and replated in expansion medium on polyornithine-coated dishes. The attached cells initially appeared as a monolayer of triangular/bipolar cells, which later grew in clusters and formed characteristic lattices (inset) 
aggregates tend to develop cavities resulting in increased cell death and generation of nonneural lineages. ESC clusters were transferred to a suspension medium (SM) and allowed to grow as spheres for 6 days, with a change in medium on alternate days (Figure 1b). The spheres were collected, gently triturated and plated on polyornithine-coated plates in expansion medium. The cultures appeared to be entirely composed of columnar neuroepithelial rosettes, with bipolar/triangular cells radiating outward. The remaining floating clusters developed multiple rosettes as well (Figure 1c). After 4-6 days in expansion medium, the C-NPCs were replated in the same medium, forming monolayer cultures of C-NPCs (Figure 1d). The cultures could be robustly amplified for up to five passages, after which most cells would stop proliferating and spontaneously differentiate. Both $\mathrm{H} 9$ and $\mathrm{H} 14$ lines yielded similar results. Data from the $\mathrm{H} 9$ cell line are presented below.

Reproducible proteomic signature of C-NPCs. To investigate the reproducibility and the robustness of rapid neuralization, we performed a comparative whole-cell proteomic analysis of two independent C-NPC derivations: (1) C-NPCs derived from ESCs at passage 35 and (2) C-NPCs derived from the same culture of ESCs that were propagated for an additional 55 passages (corresponds to an amplification of approximately $10^{15}$-fold, if the entire culture were to be expanded). Control cells included adult brainderived neural precursors (kind gift of Dr. Phil Schwartz, Children's Hospital of Orange County, Ca, USA) grown for several weeks in the same medium as C-NPCs, and the human acute monocytic leukemia cell line THP-1. We employed SELDI-MS technology (Ciphergen Biosystems Inc., Fremont, CA, USA), which combines selective adsorption onto a pretreated chip with linear TOF mass spectrometry. This technology allows fast, cost-effective, and comprehensive comparison of proteomic profiles or signatures from multiple samples. We found that the profiles of protein expression were nearly identical for the two C-NPC cultures derived many months apart (Figure 2). Despite the overall similarity between the brain-derived NPCs and C-NPC profiles, differences in the relative peak sizes can be readily discerned. The signature of the human acute monocytic leukemia THP-1 cells showed major differences from both NPC preparations. This analysis demonstrates the robust and reproducible generation of C-NPC cultures after long-term propagation (large-scale expansion) of ESCs. Although C-NPCs derived by rapid neuralization cannot be amplified beyond five passages, the straightforward and reproducible differentiation offers an easy scale-up strategy by generating a large number of C-NPCs directly from ESCs. These C-NPCs have been shown to retain the correct diploid karyotype after long-term propagation (up to 100 passages) using appropriate culture conditions. ${ }^{20,21}$

In situ characterization of C-NPCs. First, using immunochemistry and RT-PCR, we focused on known markers of neural precursors and undifferentiated cells in C-NPC cultures (Figure 3 ). We found the C-NPC cultures (after 10
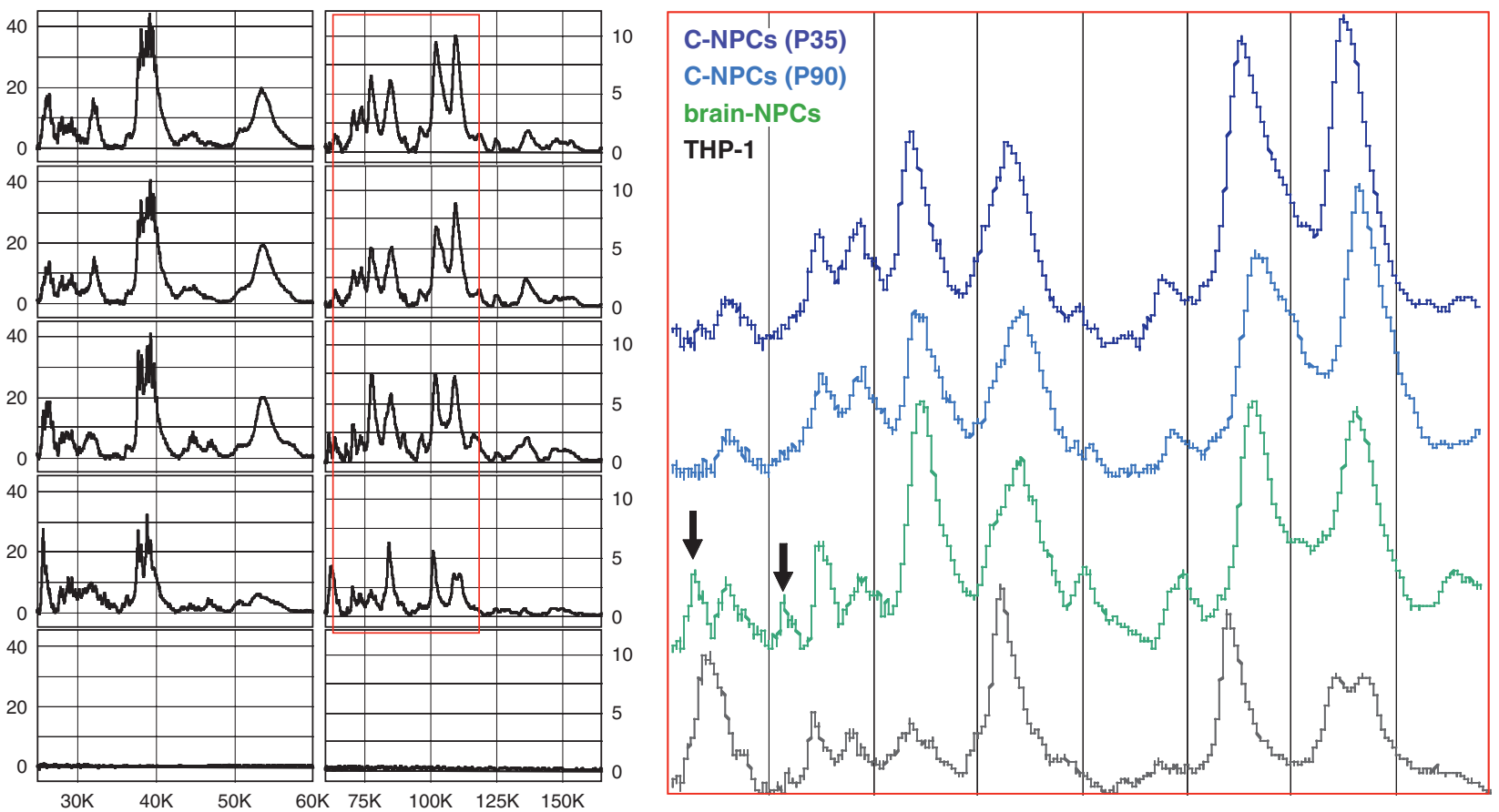

Figure 2 Proteomic profiling of C-NPCs and fetal brain-NPCs. Surface-enhanced laser desorption ionization mass spectrometry (SELDI-MS), whole-cell proteomic profiling of C-NPCs. Left panel represents the cellular proteomic profile between $30-60$ and $75-150 \mathrm{kDa}$. From top to bottom, C-NPCs derived from hESCs propagated for 35 passages; C-NPCs derived from hESCs propagated for an additional 50 passages; fetal brain derived NPCs; human acute monocytic leukemia cell line (THP1). Right panel is an expansion of the area enclosed by the red square in the left panel. Although both C-NPC profiles are virtually identical, the human fetal brain NPC profile shows apparent differences (arrows); THP1 cells have a very different proteomic signature 
a

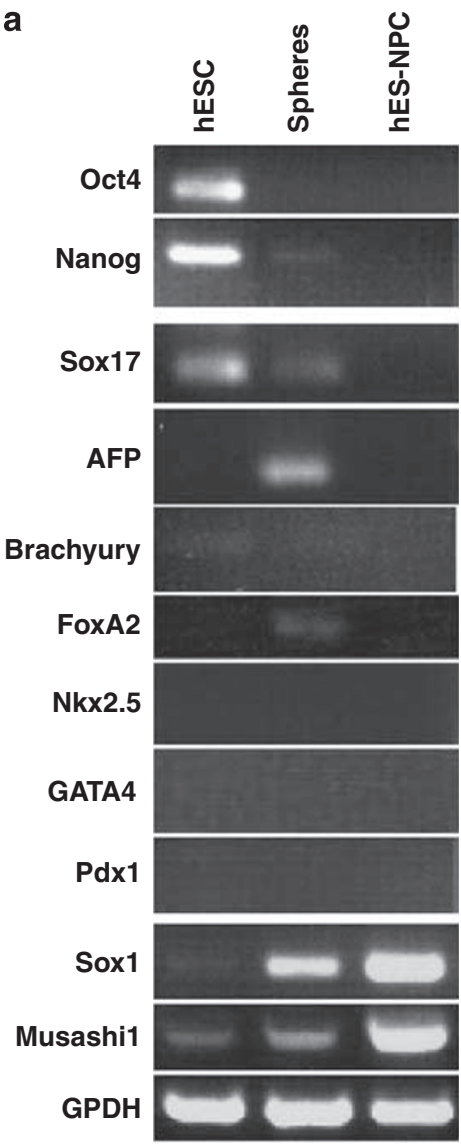

b

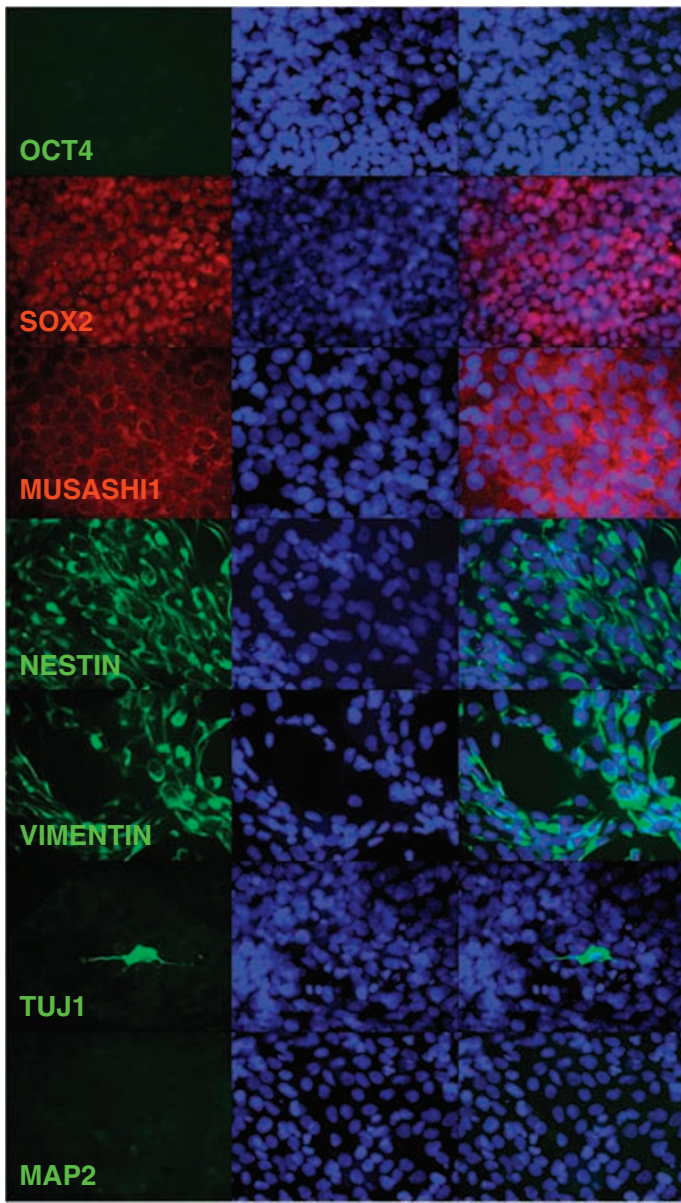

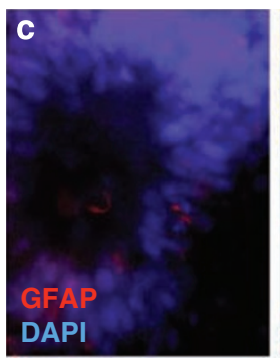
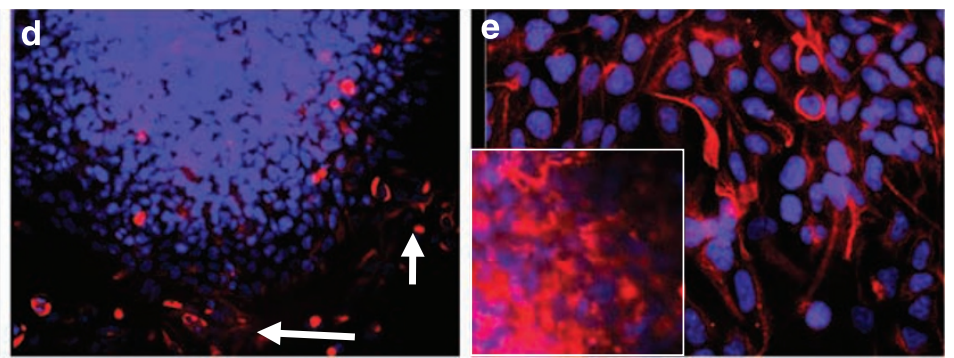

Figure 3 C-NPCs express a homogeneous array of proneural markers. (a) Analysis of markers characteristic for undifferentiated ESCs, mesoderm, and endoderm using RT-PCR in human ESCs and C-NPCs (day 12 of differentiation). (b) Immunostaining for developmental markers; left column fluorescent antibody, right column overlay with nuclear DAPI (blue). Staining for nuclear Oct4, a marker for undifferentiated human ESCs (absent); proneural markers nuclear Sox2 (uniformly present), cytoplasmic Musashi1 (uniformly present), filamentous Nestin (uniformly present); committed neuronal markers such as cytoplasmic TuJ1 $(<0.1 \%)$ and MAP2 (absent). (c) Filamentous GFAP is absent in newly derived NPCs, including rosettes. (d) Some of the cells radiating out of clusters express GFAP after the first passage. (e) After subsequent passages, most NPCs express GFAP

days of differentiation) stain uniformly positive for Sox2, Musashi1, and Nestin, and negative for Oct4, Nanog, MAP2, and GFAP (Figure $3 a$ and b). TuJ1-positive young neurons were extremely rare, confirming the undifferentiated nature of the C-NPC cultures (Figure 3b). RT-PCR analysis confirmed the absence of transcripts for Oct4 and Nanog, pluripotent ESC markers, GATA-1, a marker of primitive and definitive hematopoiesis, GATA-4, a marker for pharyngeal endoderm and cardiac derivatives, Nkx2.5, a marker of cardiac mesoderm, and PDX-1, a pancreatic tissue marker. Thus, after 10-12 days of differentiation, these cultures were uniformly positive for the neuroectodermal markers and uniformly negative for mesodermal, endodermal, and mature neuronal and glial markers (Figure 3a). These results suggest that the majority of ESCs differentiated into neuroectoderm under these defined conditions, although some nonneural lineages might have been generated and subsequently died off.

Freshly generated C-NPCs were uniformly negative for GFAP (Figure 3c); however, on passaging, cells initially 
emigrating from clusters and, eventually, all cells in the culture stained positively for GFAP (Figure $3 d$ and $f$ ). This expression pattern clearly differs from brain-derived human NPCs, which are uniformly GFAP-positive, even during early passages. ${ }^{22}$ Previous work suggested that these cells represented the radial glial phenotype of mouse ESC-derived NPCs. ${ }^{16,23}$ The acquisition of GFAP staining and the morphology of the C-NPCs at this stage are consistent with a radial glia identity.

To further address the identity of the C-NPCs, we used microarray technology to examine the mRNA expression of CNS markers of regional specification during ESC neuralization. Both anterior (Emx2, Otx2, Dlx1/2) and posterior (HoxA2, HoxB2, HoxB6) CNS markers were detected (Figures 4 and 6c). Some of the markers, such as Pax2, Gbx2, and HoxB6, were transiently upregulated during ESC neuralization to C-NPCs. In contrast, Otx 2 was found to be expressed in ESCs but was downregulated during neuralization (Figure 4a). mRNA for several other genes (e.g., FoxG1, Emx1, Nkx2.1, En1, Nkx2.6, HoxA1, HoxC5) was not detected using microarray, either due to lack of expression or low hybridization efficiency of the probes. To corroborate these microarray data, immunostaining for the anterior marker Otx2 and the posterior marker HoxB4 was performed after 7 days (168 h) of neuralization (Figure 4b). We found that the majority of day 7 C-NPCs were positive for both Otx2 and HoxB4 but with variable levels of expression. These results were obtained using medium containing B27 supplement with or without retinoic acid. The expression of mRNAs for dorsal-ventral spinal cord markers, such as Math1, Ngn1, Nkx6.1, and Nkx2.1, was not detected using microarray analysis (data not shown). These results suggest that C-NPCs are not regionally specified under our conditions and likely have broad developmental potential.

Efficient neuralization of ESCs does not require exogenous BMP inhibitors. The BMP inhibitor Noggin, commonly used to enhance neural cell fate, was not included in these defined conditions. To determine whether Noggin is dispensable for efficient neuralization of ESCs, we tested three conditions in parallel: (1) our original defined conditions; (2) original defined conditions $+100 \mathrm{ng} / \mathrm{ml}$ Noggin added during the first 5 days of differentiation; (3) original defined conditions $+20 \mathrm{ng} / \mathrm{ml}$ of BMP2 and $20 \mathrm{ng} / \mathrm{ml}$ of BMP4 added during the first 5 days of differentiation. If exogenous Noggin is dispensable for ESC neuralization, then the addition of Noggin to our defined conditions should not change the outcome of differentiation. In contrast, the addition of BMP2/4 should activate the TGF $\beta$ pathway, resulting in an altered gene expression profile and the appearance of nonneural cell fates, similar to those seen in embryoid bodies. To test this hypothesis, we monitored global gene expression changes during differentiation and investigated the status of BMP/TGF $\beta$ signaling (Figure 5). Constant levels of Smad1 and Smad4 mRNA, but not Noggin or BMP4, were detected during ESC neuralization under our neuralization conditions. BMP5 expression was upregulated at later time points concomitant with the downregulation of the BMP-inhibitor follistatin (Figure 5a). We did not observe statistically significant alterations in gene expression
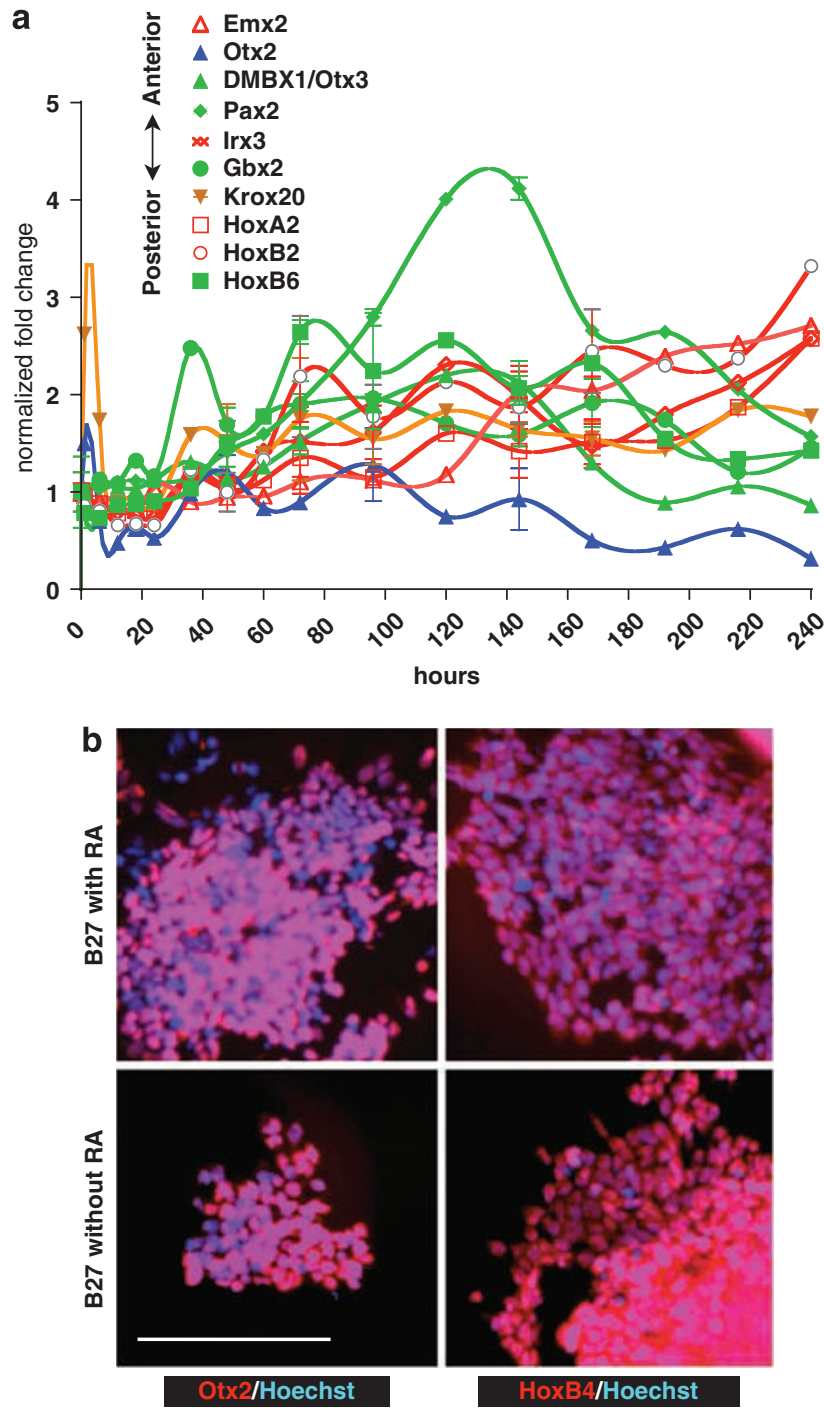

Figure 4 C-NPCs express both anterior and posterior markers of neuroectoderm. (a) Microarray analysis of anterior-posterior markers during the first 10 days of neuralization. Only mRNA transcripts with at least twofold changes are shown. Upregulated transcripts are in red, downregulated transcripts are in blue, and transiently upregulated transcripts are in green. (b) Immunostaining for anterior (Otx2) and posterior (HoxB4) neuroectoderm markers in C-NPCs differentiated for 6 days in B27 supplement with or without retinoic acid (RA). Scale bar, $200 \mu$

(averaged over the entire differentiation period) on addition of Noggin.

In contrast, BMP-treated cultures revealed major changes in gene expression (Figure $5 \mathrm{~b}$ and $\mathrm{c}$ ). Characteristically, BMP treatment resulted in downregulation of proneural genes such as Sox3 and Pax6, and upregulation of mesodermal markers such as simple epithelial keratins 8/18/19 and lymphoid or colon epithelium-associated Hox genes (B8, C6, B6). In contrast, Noggin treatment did not result in differential expression of these genes (Figure 5c). Consistent with the microarray results, phosphorylation of Smad1/5 was barely detectable in the original cultures as well as in Noggin-treated cultures. As expected, robust phosphorylation of Smad1/5 was detected in BMP-treated cultures (Figure 5d). Thus, 
812
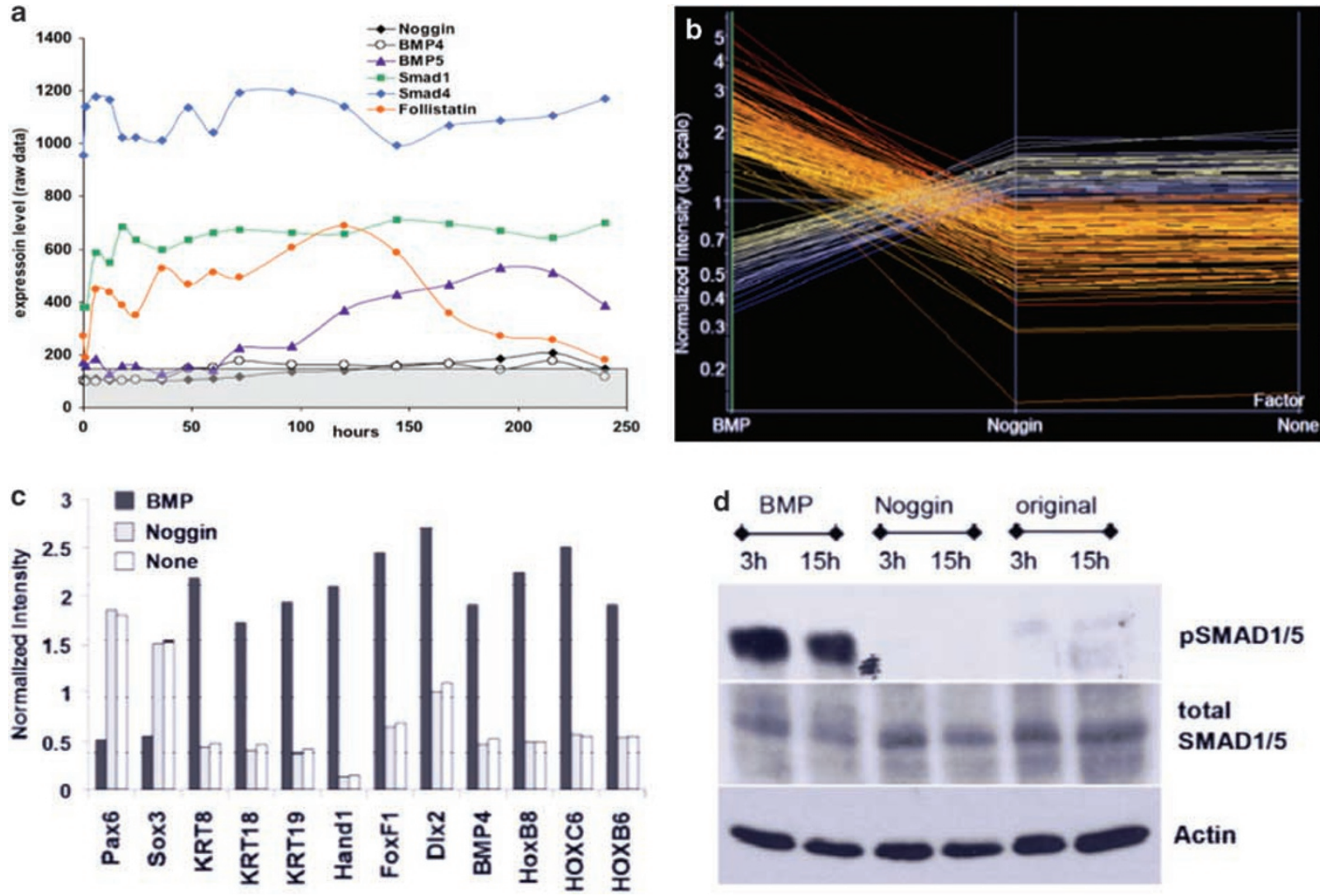

Figure 5 Exogenous BMP-inhibitors (such as Noggin) are not required for efficient neuralization of hESCs. (a) Gene expression dynamics of the Smad signaling pathway (Illumina microarrays). (b) Normalized gene expression (averaged over days 3-13 of differentiation) in C-NPCs derived in the presence of the factors BMP2/4, Noggin, or without these factors (original conditions, labeled none). Volcano plot statistics implemented in GeneSpring software identified $\sim 200$ genes that were up- or downregulated at least twofold in BMP-treated cultures compared to Noggin-treated or 'original condition' cultures. No differences were found between the Noggin-treated and the original condition cultures. Transcripts upregulated in BMP cultures are in red, transcripts downregulated are in blue. (c) Bar graph of representative examples of genes from B that were up- or downregulated in BMP cultures. (d) Western blot analysis using phopsho-Smad1/5-specific antibodies of C-NPC differentiation at 3 and $15 \mathrm{~h}$ after induction. Drastic upregulation of Smad1/5 was seen in BMP-treated cultures, as expected. Note the low level of TGF $\beta$ signaling in the Noggin-treated and the original (untreated) C-NPC cultures. Total Smad1/5 and actin proteins were used as loading controls

during our protocol for rapid neuralization of ESCs, we observed very low BMP/TGF $\beta$ signaling. Taken together, these results provide strong evidence that exogenous Noggin is dispensable for rapid and uniform neuralization of human ESCs.

Two major waves of molecular expression during ESC neuralization. To gain insight into the global molecular changes occurring during C-NPC derivation, we performed a functional whole-genome analysis, which provides a very detailed, unbiased, and robust characterization of the state of the cells. Genome analysis shows the stages that cells go through, validating their identities by identifying known markers of cell type or state, and providing a formal, unbiased basis for molecular characterization of neural progenitor differentiation.

We collected expression data at 15 time points over 10 days of differentiation, spanning the stages of undifferentiated ESCs, rosette formation, and appearance of lattice-like monolayers. We focused on the genes that changed significantly between time 0 (undifferentiated ESCs) and a given time point. At day 10 of differentiation, situated at the transition between the ESC and C-NPC stages, more than 300 mRNA transcripts were found to be up- or downregulated with various kinetics (Figure 6a). Quantification of the kinetics of expression revealed two waves of global gene expression change: the first wave occurred at $72 \mathrm{~h}$ and the second at $144 \mathrm{~h}$ of differentiation (Figure 6b; Supplementary Figure 1A). Remarkably, the first wave of change occurred in the absence of major morphological alterations and preceded the formation of columnar neuroepithelial rosettes. In particular, transcripts of FGF5, a marker of primitive ectoderm in the mouse, ${ }^{24}$ were transiently upregulated threefold at $72 \mathrm{~h}$ (first wave) but was subsequently downregulated to the basal level found in ESCs by $144 \mathrm{~h}$ (Q-PCR; Supplementary Figure 1B). To define the pathways and developmental stages that can be associated with the gene expression changes detected in the first and second waves, we performed meta-analysis of all publicly available microarray data. We employed the NextBio search engine (www.nextbio.com) that allows queries of the existing datasets using a particular gene set, including the fold change for each gene in the set. Comparison with available datasets for mouse ESC neuralization ${ }^{25}$ revealed many genes that were downregulated in both the first wave of human ESC 
a

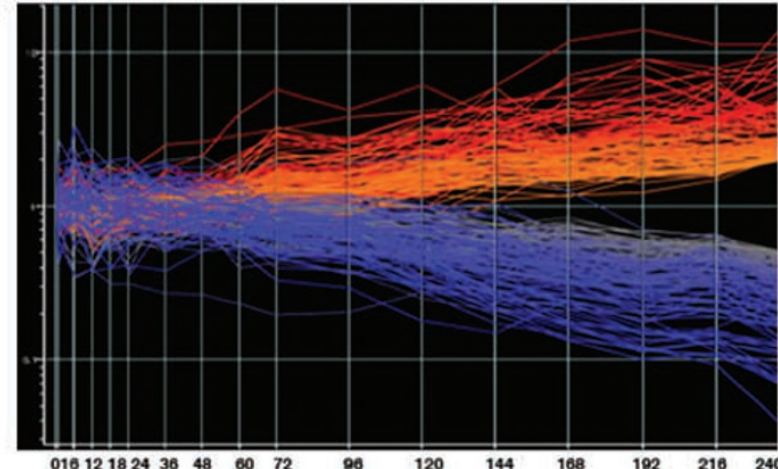

C

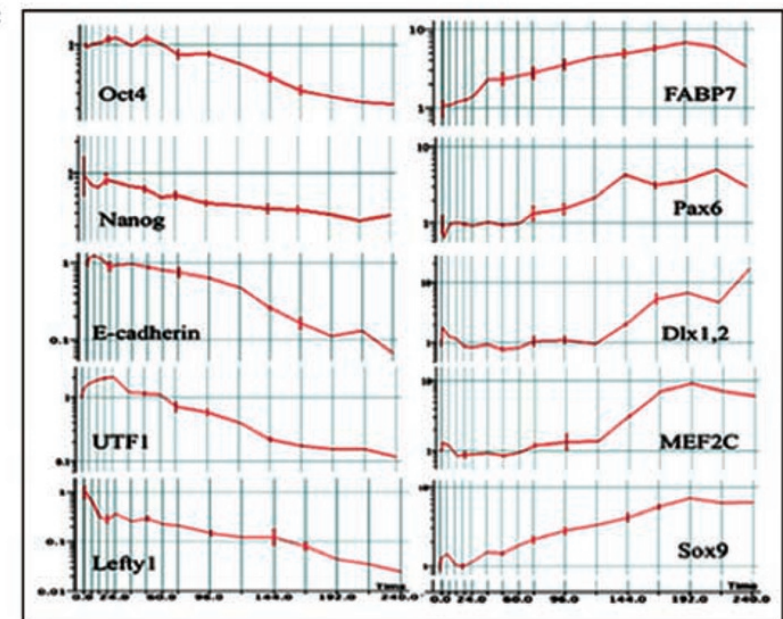

e

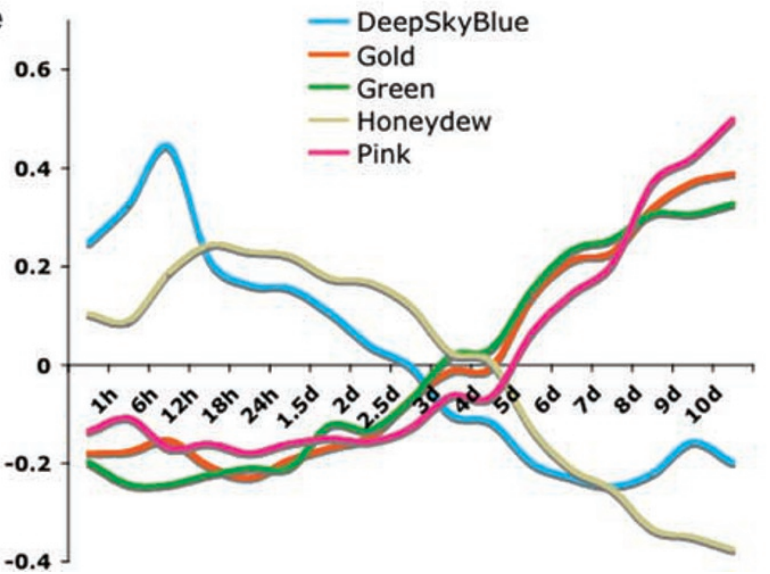

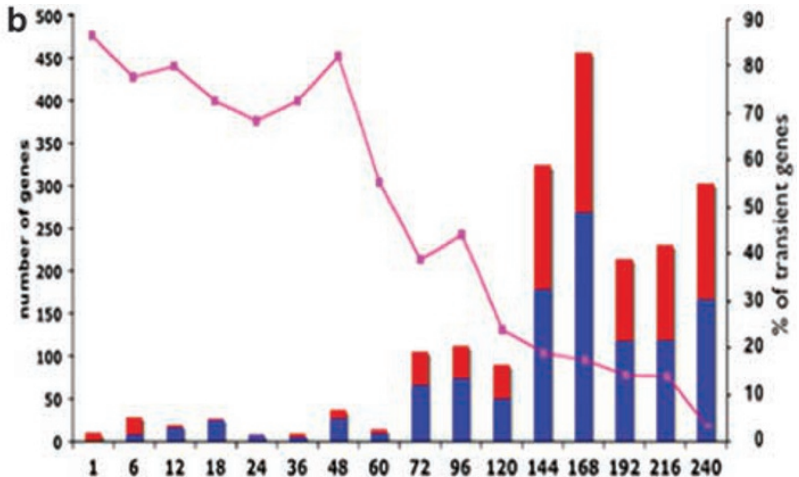

d
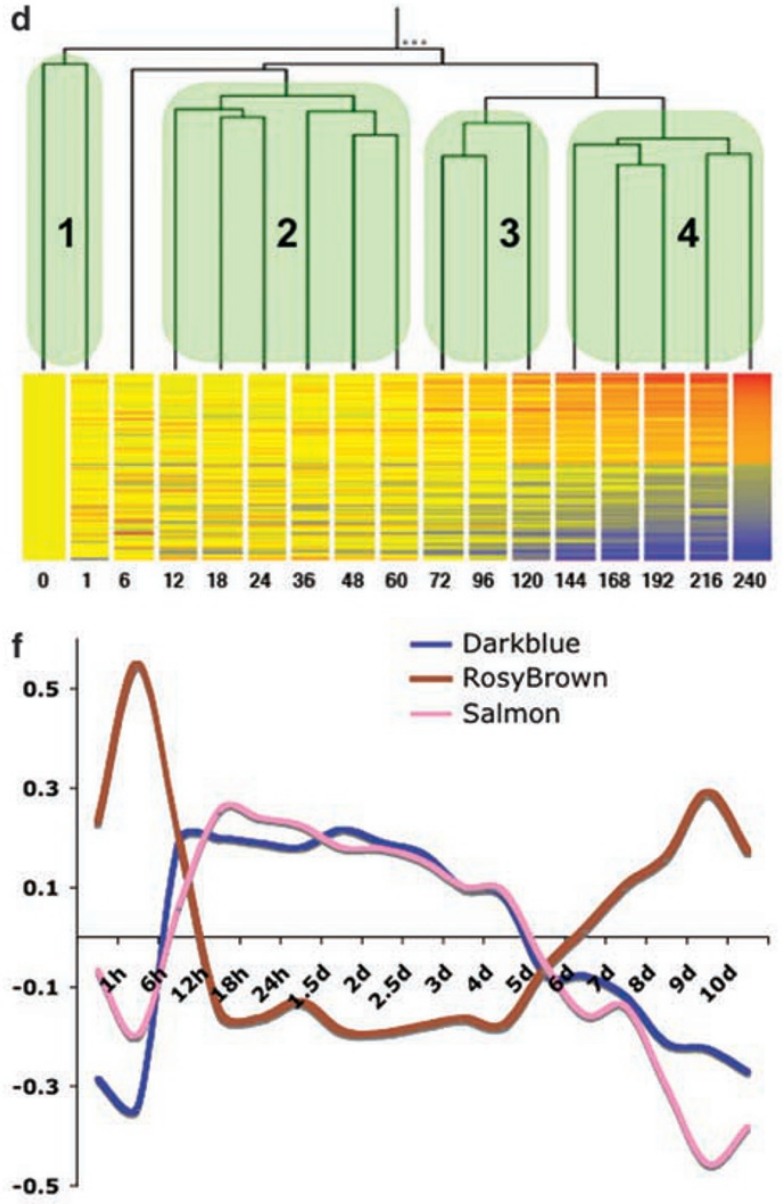

Figure 6 Gene expression analysis of hESC neuralization. (a) Volcano statistical analysis (GeneSpring) revealed about 300 genes that changed significantly ( $>2$-fold, $P<0.05)$ between the undifferentiated ESC state (time 0$)$ and C-NPC stage $(240 \mathrm{~h}$ of differentiation). Note that the major changes in gene expression began $72 \mathrm{~h}$ after differentiation, and most of the differentially regulated genes were already up- or downregulated by $144 \mathrm{~h}$. (b) Quantification of gene expression dynamics shown in (a). The number of genes upregulated (red bars) and downregulated (blue bars) between the undifferentiated ESC state and a given time point is plotted on the left ordinate axis. The pink line represents the percentage of genes transiently up- or downregulated at a given time point on the right ordinate axis. (c) Characteristic examples of downregulated genes (Oct4, Nanog, E-cadherin, UTF1, Lefty1) and upregulated genes (FABP7, Pax6, Dlx1/2, MEF2C, Sox9) consistent with loss of the undifferentiated ESC phenotype and acquisition of the neural phenotype. (d) Upper panel: unsupervised hierarchical clustering identified four clusters of gene expression during ESC neuralization (shaded in lightgreen). Lower panel: color-coded diagram of upregulated genes (red lines) and downregulated genes (blue lines) at multiple time points (in hours). (e and f) WGCNA analysis identified two types of expression modules: type 1, transiently up- or downregulated modules (e); and type 2, permanently up- or downregulated modules (f)

neuralization and in mouse (comprising $\sim 60 \%$ of all gene changes in the first wave). During the second wave, a significant number of both up- and downregulated genes were shared with mouse neural progenitors (representing $\sim 80 \%$ of all gene changes in the second wave), suggesting that the second wave of changes in gene expression is likely associated with neural commitment (Supplementary Figure $2 \mathrm{~A}$ and $\mathrm{C})$. 
Indeed, querying developmental expression datasets revealed that the gene expression profile in the first wave was associated with early developmental events such as organ development, regionalization, organ morphogenesis, as well as neural crest and neural tube development. In contrast, the second wave was more selectively associated with later events such as central nervous system development, brain development, and neurogenesis (Supplementary Figure 2B and C; see Supplementary Tables 1 and 2 for a complete list of gene changes during the first and second waves, respectively). The percentage of differentially regulated transcripts that varied transiently dropped from 80 to $20 \%$ between 48 to $144 \mathrm{~h}$ of differentiation and then dropped further below $5 \%$ at $240 \mathrm{~h}$ (Figure $6 \mathrm{~b}$ ). Taken together, these results suggest the presence of a transient state characterized by differential gene expression between 48 and $144 \mathrm{~h}$ of differentiation, which precedes the formation of neuroepithelial rosettes. On the other hand, stable gene expression profiles, likely corresponding to a defined cell population, emerge at approximately 10 days of differentiation.

Similar to other reports on human ESC neuralization, we observed downregulation of Oct4, Nanog, UTF1, E-cadherin, and Lefty, consistent with complete loss of the pluripotent phenotype typical of human ESCs. Concomitantly, we observed upregulation of FABP7, PAX6, DIx, MEF2C, and Sox9, consistent with acquisition of the neural phenotype (Figure 6c). ${ }^{26,27}$ However, we observed faster downregulation of known pluripotency markers, such as Oct4 and Nanog, compared to previously published neuralization procedures. ${ }^{13-15}$ We also found that neural-related transcripts were induced with different kinetics, consistent with their role in neural development. For example, the radial glia marker, FABP7, and the transcription factor regulating gliogenesis and development of neural crest lineage, Sox9, were upregulated very early during ESC differentiation (in the first wave of gene expression change), corresponding to the their developmentally controlled temporal expression. ${ }^{28}$ In contrast, transcription factors such as DIx1/2 and MEF2C, which are involved in neuronal specification and migration, were upregulated during the second wave of differentiation, again consistent with their expression during neuronal developmental (Figure 6c). ${ }^{29}$

In addition to the selective survey of known genes, we used an unbiased approach, based on unsupervised hierarchical clustering (GeneSpring software). This analysis grouped the samples into four main clusters, which correspond to discrete temporal epochs during ESC neuralization (Figure 6d). The first cluster consisted of undifferentiated ESCs, encompassing the genes associated with the pluripotent state. The second cluster encompassed the 'latent period' between 12 and $48 \mathrm{~h}$ of differentiation, which was characterized by minimal changes in gene expression when compared to ESCs. Only a few genes (25-30) within the second cluster varied at any time point. This cluster consisted primarily of genes whose up- or downregulation was transient, and most genes $(70-80 \%)$ returned to baseline after this period. The third and the fourth clusters corresponded to the two major waves of change in gene expression (days 3 and 6), as identified above through differential gene expression analysis, thus providing an independent validation for these findings.
Curiously, several developmentally controlled genes were transiently upregulated, peaking at approximately $120 \mathrm{~h}$, a time in between the two major waves of change in gene expression. These genes include: $L M O 1, I R X 1$, and $P A X 2$. LMO1 is a transcriptional regulator involved in the Hoxdependent regulatory network for hindbrain patterning and contributes to leukemogenesis in concert with OLIG2; IRX1 is a member of the Iroquois homeobox gene family, playing multiple roles during pattern formation of vertebrate embryos; and PAX2 is a paired box transcription factor, implicated in the renal-coloboma syndrome characterized by ocular, renal, and CNS anomalies. Although the roles of $L M O 1, I R X$, and PAX2 in neurogenesis have not been documented because of the timing of their expression, we speculate that these genes may play critical roles in neuralization of ESCs, in particular during very early specification of neuroepithelial fates.

Analysis of gene coregulation identifies several functional modules. To move beyond lists of differential expression and explore the higher-order organization of gene expression at a systems level as it relates to ESC neuralization, we applied a weighted gene coexpression network analysis (WGCNA). ${ }^{30}$ Viewing the dataset in this manner provided a complementary framework for analysis of transcriptional regulation during ESC neuralization. We and others have shown that this method allows one to define the transcriptome structure and to visualize modules of coexpressed genes that correspond to functional units. ${ }^{30,31}$ Briefly, the absolute Pearson correlations between any one gene and every other gene on the array were computed, weighted, and used to determine the topological overlap (TO), which is a measure of connection strength or neighborhood sharing. Then, genes were clustered based on TO, and groups of highly interconnected genes (modules, identified by color names) were identified (Figure 6e). Modules were annotated using gene ontology (GO) and ingenuity pathway analysis (www.ingenuity.com) to aid in assigning the functional relevance of genes and pathways in each module (Table 1).

WCGNA identified two major types of modules present during ESC neuralization. The first type was characterized by a group of genes that coordinately change expression levels around 3-5 days of differentiation (Figure 6e). Within this class, we found modules characterized by changes occurring early (day 3: DeepSkyBlue module) and late (day 5: Pink module), consistent with the two waves of expression changes identified by the standard analysis for differential expression (Figure $6 \mathrm{~b}$ and $\mathrm{d}$ ). Several modules (Gold, Honeydew, and Green) showed pronounced biphasic behavior, following the transition points at days 3 and 5 but with minimal changes in between (Figure 6e). This result is consistent with the emergence of the transient but defined genetic/cellular state during ESC neuralization as proposed above. The WGCNA analysis also revealed upregulation of several classical pathways, such as $\mathrm{Wnt} / \beta$-catenin, integrin, leukocyte extravasation signaling, $\mathrm{G}_{2} / \mathrm{M}$ checkpoint regulation, and nicotinamide metabolism, known to play roles in ESC neuralization and to be functionally important in neural precursors. Indeed, the role of the $\mathrm{Wnt} / \beta$-catenin pathway in the neuralization process, ${ }^{32}$ the critical importance of 
Table 1 Functional GOTERM annotation of the expression modules (represented by the Hub genes) identified by WGCNA/Ingenuity analysis of $h E S C$ differentiation into neural progenitors

\begin{tabular}{|c|c|c|c|c|c|c|c|c|c|}
\hline & DarkBlue & Salmon & RosyBrown & Wheat & DeepSkyBlue & Honeydew & Gold & Green & Pink \\
\hline $\begin{array}{l}\text { Biological } \\
\text { process }\end{array}$ & $\begin{array}{l}\text { Regulation of } \\
\text { nucleoside, } \\
\text { nucleotide, and } \\
\text { nucleic acid } \\
\text { metabolism }\end{array}$ & $\begin{array}{l}\text { RNA metabolism, } \\
\text { ribosome } \\
\text { biogenesis, and } \\
\text { assembly }\end{array}$ & $\begin{array}{l}\text { Glucose } \\
\text { metabolism, } \\
\text { carbohydrate } \\
\text { catabolism }\end{array}$ & $\begin{array}{l}\text { Cell cycle, } \\
\text { response to } \\
\text { stress, alcohol } \\
\text { metabolism, } \\
\text { cholesterol } \\
\text { biosynthesis }\end{array}$ & $\begin{array}{l}\text { Muscle } \\
\text { development } \\
\text { regulation, I- } \kappa \mathrm{B} / \\
\mathrm{NF}-\kappa \mathrm{B} \text { cascade, } \\
\text { morphogenesis } \\
\text { apoptosis }\end{array}$ & $\begin{array}{l}\text { Cellular } \\
\text { metabolism, } \\
\text { programmed cell } \\
\text { death, } \\
\text { intracellular } \\
\text { protein transport }\end{array}$ & $\begin{array}{l}\text { Intracellular } \\
\text { protein transport, } \\
\text { protein } \\
\text { metabolism }\end{array}$ & $\begin{array}{l}\text { Nervous system } \\
\text { development, } \\
\text { neuron } \\
\text { differentiation }\end{array}$ & $\begin{array}{l}\text { CNS development, } \\
\text { M-phase of mitotic } \\
\text { cell cycle }\end{array}$ \\
\hline $\begin{array}{l}\text { Cellular } \\
\text { compartment }\end{array}$ & $\begin{array}{l}\text { Nucleoplasm } \\
\text { nucleus }\end{array}$ & $\begin{array}{l}\text { Intracellular } \\
\text { membrane-bound } \\
\text { organelle, } \\
\text { cytoplasm }\end{array}$ & $\begin{array}{l}\text { Cytosol, } \\
\text { mitochondrial } \\
\text { outer membrane, } \\
\text { endoplasmic } \\
\beta \text {-reticulum }\end{array}$ & $\begin{array}{l}\text { Collagen } \\
\text { anchoring, } \\
\text { cytoplasm, } \\
\text { extracellular } \\
\text { matrix, } \\
\text { endoplasmic } \\
\text { reticulum }\end{array}$ & $\begin{array}{l}\text { Membrane-bound } \\
\text { organelle, spindle } \\
\text { microtubule, lytic } \\
\text { vacuole, } \\
\text { lysosome }\end{array}$ & $\begin{array}{l}\text { Intracellular } \\
\text { membrane- } \\
\text { bound organelle }\end{array}$ & $\begin{array}{l}\text { Intracellular } \\
\text { membrane- } \\
\text { bound organelle }\end{array}$ & $\begin{array}{l}\text { Chromosome, } \\
\text { pericentric region, } \\
\text { nuclear } \\
\text { heterochromatin }\end{array}$ & $\begin{array}{l}\text { Intracellular } \\
\text { membrane-bound } \\
\text { organelle }\end{array}$ \\
\hline $\begin{array}{l}\text { Molecular } \\
\text { function }\end{array}$ & $\begin{array}{l}\text { Protein binding, } \\
\text { DNA binding, } \\
\text { RNA binding }\end{array}$ & $\begin{array}{l}\text { RNA-binding } \\
\text { protein-binding } \\
\text { catalytic activity, } \\
\text { methyl- } \\
\text { transferase } \\
\text { activity }\end{array}$ & $\begin{array}{l}\text { L-ascorbic acid } \\
\text { binding, } \\
\text { dioxygenase } \\
\text { activity, Fe-ion } \\
\text { binding, vitamin } \\
\text { binding }\end{array}$ & $\begin{array}{l}\text { Nucleotide } \\
\text { binding, } \\
\text { transferase } \\
\text { activity, Mg-ion } \\
\text { binding, ATP } \\
\text { binding }\end{array}$ & $\begin{array}{l}\text { Cd-, Cu-ion } \\
\text { binding, protein } \\
\text { nucleotide binding, } \\
\text { protein GTPase } \\
\text { activity }\end{array}$ & $\begin{array}{l}\text { Catalytic activity, } \\
\text { nucleotide } \\
\text {, binding, methyl- } \\
\text { transferase } \\
\text { activity }\end{array}$ & $\begin{array}{l}\text { Serine/threonine } \\
\text { kinase activity, } \\
\text { small protein } \\
\text { conjugating } \\
\text { enzyme activity, } \\
\text { ligase activity, } \\
\text { transferase } \\
\text { activity }\end{array}$ & $\begin{array}{l}\text { Cytoskeletal } \\
\text { protein binding, } \\
\text { small GTPase } \\
\text { regulator, } \\
\text { transcription } \\
\text { coactivator }\end{array}$ & $\begin{array}{l}\text { Mg-ion binding, } \\
\text { GTPase activator, } \\
\text { Zn-ion binding, } \\
\text { RNA Pol II } \\
\text { transcription } \\
\text { regulator }\end{array}$ \\
\hline $\begin{array}{l}\text { Functional } \\
\text { categories }\end{array}$ & $\begin{array}{l}\text { DNA binding, } \mathrm{Zn}- \\
\text { finger, transcription } \\
\text { regulation }\end{array}$ & $\begin{array}{l}\text { RNA binding, } \\
\text { nucleotide } \\
\text { binding, } \\
\text { alternative } \\
\text { splicing, ATP } \\
\text { binding }\end{array}$ & $\begin{array}{l}\text { Glycolysis, } \\
\text { oxidoreductase, } \\
\text { membrane } \\
\text { gluconeogenesis }\end{array}$ & $\begin{array}{l}\text { Cholesterol } \\
\text { biosynthesis, } \\
\text { extracellular } \\
\text { matrix, isoprene } \\
\text { biosynthesis, } \\
\text { sterol } \\
\text { biosynthesis }\end{array}$ & $\begin{array}{l}\text { Metal-thiolate } \\
\text { cluster, Zn, Cd } \\
\text { chelation }\end{array}$ & $\begin{array}{l}\text { Phosphorylation, } \\
\text { nuclear protein, } \\
\text { transit peptide } \\
\text { phosphoprotein, } \\
\text { ATP binding }\end{array}$ & $\begin{array}{l}\text { Phosphorylation, } \\
\text { nuclear protein } \\
\text { serine/threonine } \\
\text { protein kinase, } \\
\text { UBL conjugation, } \\
\text { ATP binding }\end{array}$ & $\begin{array}{l}\text { Cytoskeleton, } \\
\text { development } \\
\text { regulator, } \\
\text { membrane } \\
\text { transferase, } \\
\text { cell adhesion }\end{array}$ & $\begin{array}{l}\text { DNA binding, } \mathrm{Zn} \text { - } \\
\text { finger, TPR repeat, } \\
\text { development } \\
\text { regulator }\end{array}$ \\
\hline $\begin{array}{l}\text { Top canonical } \\
\text { pathways }\end{array}$ & $\begin{array}{l}\text { Estrogen, } \\
\text { glutamate, death } \\
\text { receptor, PPAR } \\
\text { signaling, } \mathrm{G}_{1} / \mathrm{S} \\
\text { checkpoint }\end{array}$ & $\begin{array}{l}\text { Nucleotide } \\
\text { metabolkism } \\
\text { protein } \\
\text { ubiquitination, } \\
\text { t-RNA } \\
\text { biosynthesis, } \\
\text { oxidative } \\
\text { phosphorylation }\end{array}$ & $\begin{array}{l}\text { Glycolysis/ } \\
\text { gluconeogenesis, } \\
\text { pentose } \\
\text { phosphate, } \\
\text { fructrose, } \\
\text { mannose, starch, } \\
\text { sucrose, inositol } \\
\text { metabolism }\end{array}$ & $\begin{array}{l}\text { Hepatic fibrosis, } \\
\text { aryl hydrocarbon } \\
\text { signaling, } \mathrm{G}_{1} / \mathrm{S} \\
\text { checkpoint, } \\
\text { TGF } \beta \text {, ERK/ } \\
\text { MAPK signaling }\end{array}$ & $\begin{array}{l}\text { Axonal guidance, } \\
\text { TGF } \beta \text {, actin } \\
\text { cytoskeleton } \\
\text { signaling, NRF2- } \\
\text { meditated } \\
\text { oxidative stress } \\
\text { response, ephrin } \\
\text { receptor signaling }\end{array}$ & $\begin{array}{l}\text { Purine } \\
\text { metabolism, } \\
\text { actin, insulin } \\
\text { receptor } \\
\text { signaling, } \\
\text { axonal } \\
\text { guidance, } \\
\text { NRF2-mediated } \\
\text { oxidative stress } \\
\text { response }\end{array}$ & $\begin{array}{l}\text { Protein } \\
\text { ubiquitination, } \\
\text { NRF2-mediated } \\
\text { stress response, } \\
\text { p53 signaling, } \\
\mathrm{G}_{2} / \mathrm{M} \text { checkpoint, } \\
\text { integrin signaling }\end{array}$ & $\begin{array}{l}\text { Axonal guidance, } \\
\text { Wnt/ } \beta \text {-catenin, } \\
\text { integrin signaling, } \\
\text { leukocyte } \\
\text { extravasation } \\
\text { signaling, ERK/ } \\
\text { MAPK signaling }\end{array}$ & $\begin{array}{l}\text { Aryl hydrocarbon } \\
\text { receptor signaling, } \\
\text { inositol phosphate } \\
\text { metabolism, actin } \\
\text { cytoskeleton } \\
\text { signaling, axonal } \\
\text { guidance, } \\
\text { nicatinamide } \\
\text { metabolism }\end{array}$ \\
\hline
\end{tabular}


Table 2 The Hub genes identified by the WGCNA analysis of hESCs differentiation into neural progenitors

\begin{tabular}{lllllllll}
\hline DarkBlue & Salmon & RosyBrown & Honeydew & Gold & Green & Pink & DeepSkyBlue & Wheat \\
\hline MIDN & PNUTL1 & ICAM5 & RAB15 & SPOP & RAl1 & TTC3 & F2RL1 & RAB38 \\
Mark2 & STX8 & ANGPTL4 & DBC1 & PODXL & MLLT3 & LOC387640 & LNK \\
DAP3 & PLCD1 & BNIP3 & DNMT3B & DIAPH2 & USP3 & SSBP2 & TNFRSF12A & RAB20 \\
APAF1 & HF10 & INSIG2 & SCGB3A2 & CCNI & CLDN7 & COL2A1 & HLDA1 & ZDHHC19 \\
SLC21A11 & WBSCR24 & ANG & LOC138255 & PCMT1 & MAGED2 & KIAA0918 & ISG20 & MAP4K1 \\
C1ORF19 & FLJ35827 & SPAG4 & WBSCR20A & SIRT1 & TMSNB & TTLL1 & KREMEN2 & TLE2 \\
TRN-SR & SDCCAG16 & HIG2 & & SSA2 & CKMT1 & FXYD6 & C20ORF139 & QSCN6 \\
LARP & & JMJ1 & & SNTB2 & JAM3 & TTC3 & EMILIN2 & ELL2 \\
HMM14202 & & P4HA2 & & ZNF275 & C6ORF33 & LOC387640 & HAND1 & SAV1 \\
FLJ10816 & & P4HA1 & & C20ORF53 & & & & \\
\hline
\end{tabular}

The module names are on top

leukocyte extravasation signaling in neural stem cellmediated immunomodulation, ${ }^{33}$ and the intriguing role of metabolism in proliferation of neural precursors ${ }^{34}$ have been previously documented. Together, these findings validate the WGCNA analysis performed here.

Functional annotation showed that the pathways represented in the early DeepSkyBlue module are involved in the regulation of programmed cell death, the $\mathrm{I}_{\kappa} \mathrm{B} / \mathrm{NF}-\kappa \mathrm{B}$ pathway, and morphogenesis (Table 1). The early Green module encompasses genes involved in development of the nervous system and neuronal differentiation, including cytoskeletal proteins, small GTPases, and transcriptional regulators. The late Gold module represents genes involved in cellular metabolism and intracellular protein transport. The late Pink module includes genes involved in the control of the $M$ phase of the cell cycle, regulators of RNA Polymerase II, proteins with GTPase activity, and zinc-finger containing proteins. This analysis identified novel candidate pathways and genes likely to play roles in ESC neuralization (see description of the 'Hub' genes below).

The second major class of modules showed changes at very early time points. Characteristically, these changes were transient, mostly reverting to baseline after day 5 of neuralization (Figure 6f). In this case, WGCNA complemented the standard analysis, demonstrating that the changes occurring at early time points were not noise but rather exemplary of functional organization. These results are consistent with the previous analysis suggesting the presence of a transient genetic/cellular state between 72 and $120 \mathrm{~h}$ and the emergence of a more definitive cell population after $144 \mathrm{~h}$ of neuralization. Functional annotation of these modules revealed involvement of zinc-finger transcriptional regulators (DarkBlue), RNA metabolism and ribosome assembly (Salmon), and glucose and carbohydrate metabolism (RosyBrown). Collectively, in these modules, several canonical pathways, affecting estrogen, glutamate, death receptor signaling, peroxisome proliferator-activated receptor (PPAR) signaling, and oxidative phosphorylation, were found to be transiently upregulated. Glycolysis/gluconeogenesis, pentose phosphate, fructose, mannose, starch, and sucrose metabolism were transiently downregulated (RosyBrown). This finding is consistent with a connection between intermediary energy metabolism and progenitor cell proliferation. ${ }^{34}$ Thus, in addition to known genes and signaling cascades, a number of new pathways were identified by the WGCNA approach, providing the impetus for future investigations into their potential role in neural development.

Another advantage of WCGNA is that each functional module is represented by a collection of Hub genes, which are defined as the 'most connected' or most central genes within the module's network. The expression dynamic of a Hub gene represents the first principal component of the expression profiles within a module. ${ }^{30}$ We have identified a number of Hub genes within each module, and their expression profile and connectivity with other genes suggest intimate involvement in the neuralization process (Table 2; Visant or spider plots, Supplementary Figures 3-11). This approach also provides the basis for gene discovery, using a 'guilt by association' approach. ${ }^{30,35}$ Indeed, our analysis has identified many hypothetical Hub genes, suggesting their importance for future functional studies. For example, the Green module encompasses genes and pathways classically associated with neuronal differentiation and CNS development (Tables 1 and 2). The graphical representation of gene connectivity in the Green module (Supplementary Figure 8) illustrates that several of the most connected genes (Hubs) are well-known key regulators of neuronal differentiation and CNS development. As corroboration, RAl1 deficiency in mice causes learning impairment and motor dysfunction, ${ }^{36}$ and JAM3deficient mice exhibit loss of integrity of the myelin sheath and defective nerve conduction. ${ }^{37}$ Hub genes such as TMSNB, MLLT3, and MAGED2 were previously associated with various forms of neoplasia and are highly connected to RAl1. We propose that these and other Hub genes identified in this study are candidates as key players in ESC differentiation into neural stem/progenitor cells, not only in vitro but also in vivo during normal human development.

In vitro differentiation of C-NPCs. With our approach, we were able to efficiently differentiate cultures of homogeneous C-NPCs into the three major neural subtypes: neurons, astrocytes, and oligodendrocytes (Figure 7). Abundant neurons, staining positively for $\beta$ III-tubulin (TuJ1), MAP2, and NSE were detected after 2-3 weeks of differentiation (Figure $7 \mathrm{a}-\mathrm{e}$ and j). Bipolar as well as multipolar stellate GFAP-positive astrocytes were also detected (Figure 7b-d; Supplementary Figure 11). In mice, dividing GFAP-expressing precursors in the adult subependymal zone have a bipolar or unipolar phenotype that differs from nondividing multipolar stellate astrocytes. ${ }^{38}$ In the absence of a robust 

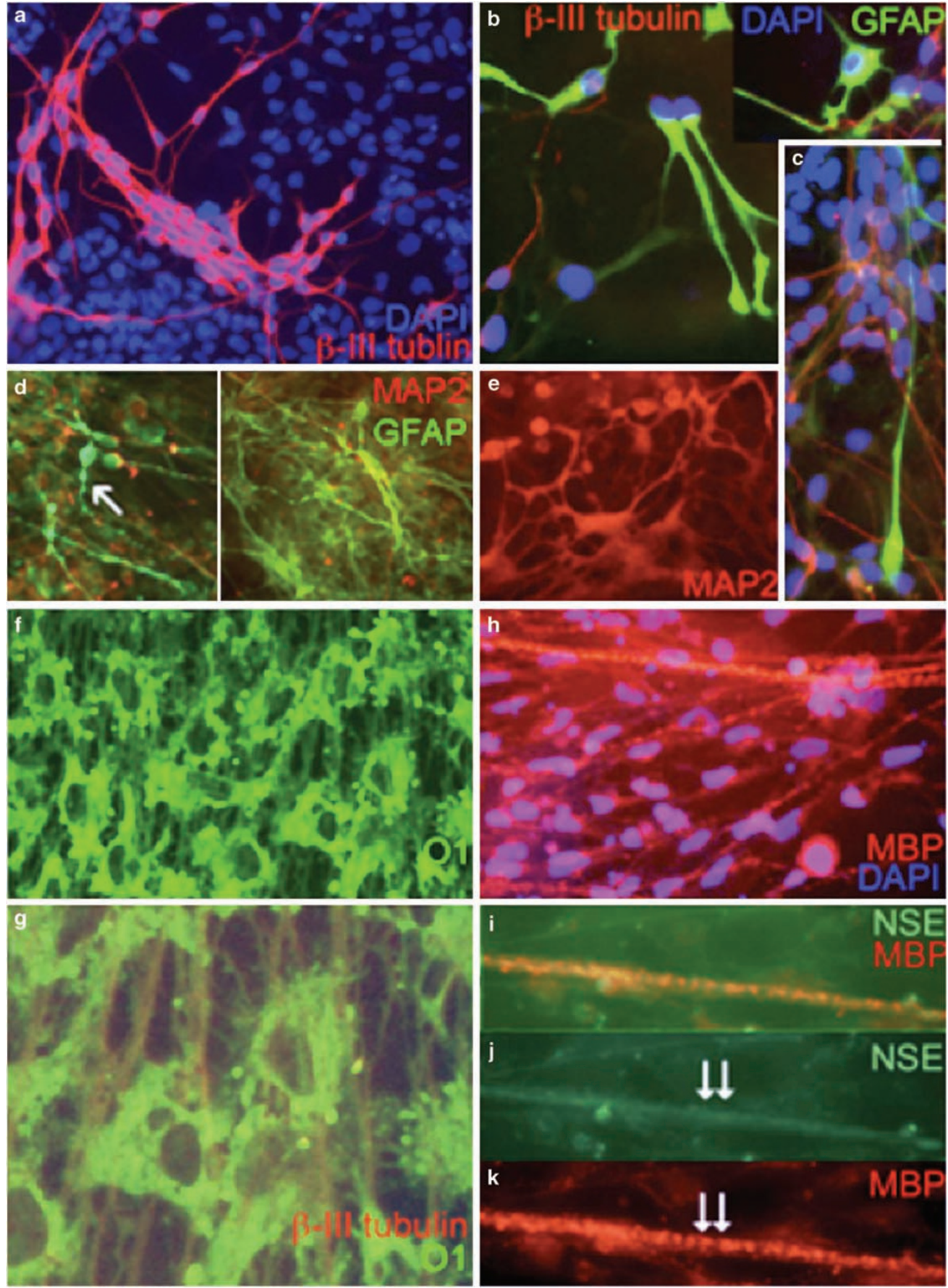

Figure 7 Differentiation of C-NPCs results in abundant neurons and oligodendrocytes capable of in vitro myelination of neuronal processes. (a-c) Young neurons stained for $\beta$ III-tubulin (TuJ1). Cell nuclei are counterstained with DAPI. (b-f) Various types of neural cells are represented, as illustrated by MAP2, GFAP, and 01 staining. (g) 01positive cells were often found alongside $\beta$ III-tubulin (TuJ1)-positive neuronal processes. (h) Many cells expressed myelin basic protein (MBP) after 3 weeks of differentiation. (i-k) MBP staining overlapped (arrows) with neural processes positive for Neuron Specific Enolase (NSE) 
marker that distinguishes multipotent dividing neural precursor cells from mature astrocytes, the distinctive cell morphologies of GFAP-positive cells suggest (but, certainly, do not prove) the presence of both cell types during our in vitro differentiation of C-NPCs. Surprisingly, after 2 weeks of differentiation, many O1-positive cells were observed, suggestive of oligodendrocytes (Figure 7f). Costaining for $\mathrm{O} 1$ and TuJ1 revealed numerous 01 -positive processes that closely paralleled the TuJ1-positive neuronal processes (Figure 7g). After 3 weeks of differentiation, multiple processes that stained positively for MBP were also detected (Figure $7 \mathrm{~h}$ ). Many processes also stained for both neuron-specific enolase (NSE) and MBP (Figure 7i-k). The close juxtaposition of neuronal (TuJ1) and oligodendrocyte
(O1, MBP) markers raises the possibility that some C-NPCs differentiated into oligodendrocytes, which in turn initiated in vitro myelination of neuronal processes generated in the same culture.

Electrophysiology and digital calcium imaging of neurons derived from C-NPCs. To address the functional properties of neurons detected by immunostaining, we performed calcium imaging and patch-clamp recording. C-NPC cultures that had been differentiated for 4 weeks were loaded with Fura-2/AM and exposed to $\mathrm{N}$-methylD-aspartate (NMDA). We observed robust $\mathrm{Ca}^{2}+$ responses in individual cells from several independent cultures
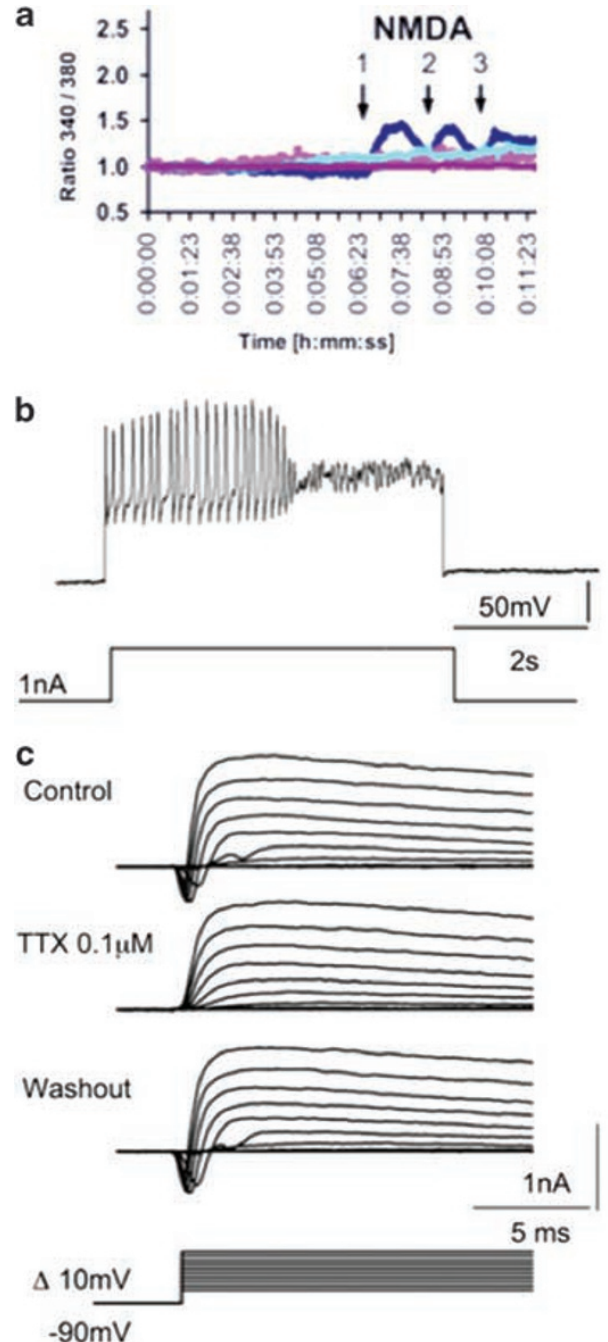

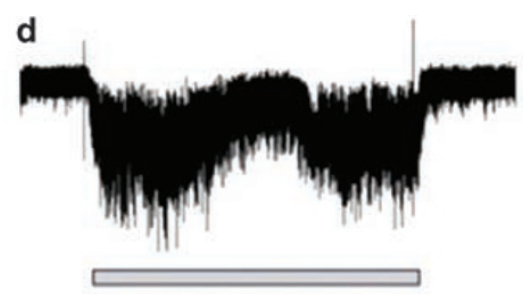

Glut $100 \mu \mathrm{M}+$ Gly $20 \mu \mathrm{M}$
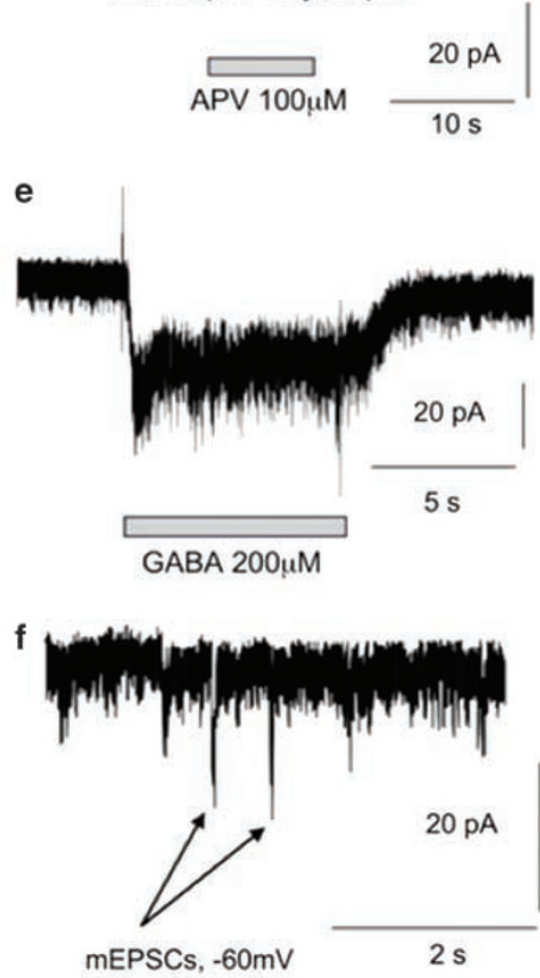

Figure 8 Characterization of differentiated C-NPCs as neurons using physiological criteria. NMDA evoked increases in $\left[\mathrm{Ca}^{2+}\right]$ in numerous cells derived from C-NPCs that had been cultured for 2-4 weeks. (a) Fura-2-loaded cells were exposed to NMDA ( $100 \mu \mathrm{M}$ at $37^{\circ} \mathrm{C}$ ). Changes in calcium levels in response to NMDA (dark blue) are shown relative to baseline conditions (before NMDA in purple and following NMDA in light blue). (b) Action potentials triggered by depolarization in current-clamp mode. (c) Voltage-gated $\mathrm{Na}^{+}$currents recorded after 4 weeks of differentiation. Whole-cell recording in voltage-clamp mode. The fast $\mathrm{Na}^{+}$currents were reversibly blocked by $0.1 \mu \mathrm{M}$ TTX. Stimulation consisted of $100 \mathrm{~ms}$ voltage steps in $10 \mathrm{mV}$ increments from -60 to $+30 \mathrm{mV}$ from a holding potential of $-60 \mathrm{mV}$ following a $300 \mathrm{~ms}$ hyperpolarizing prepulse to $-90 \mathrm{mV}$. (d and e) Ligand-gated currents, recorded under voltage clamp, from differentiated hESCs after 2.5 weeks in culture. Glutamate-evoked currents (in the presence of glycine) were partially inhibited by APV, consistent with the presence of NMDA receptor-gated currents. In other cells, GABA elicited peak currents in excess of $40 \mathrm{pA}$, indicating the presence of inhibitory receptors. Holding potential $-60 \mathrm{mV}$. (f) Spontaneous mEPSCs, recorded in voltage-clamp mode, after 2 weeks of differentiation. Holding potential $-60 \mathrm{mV}$ 
(Figure 8a), suggesting the presence of the NMDA-subtype of glutamate receptor on at least $0 \%$ of cells in the cultures.

To unambiguously document the presence of these receptors as well as other ligand-and voltage-gated currents that should be develop in maturing neurons, we performed whole-cell recordings with patch electrodes on C-NPCs after 4 weeks of differentiation. About $10 \%$ of the cells displayed action potentials typical of neurons (Figure $8 \mathrm{~b}$ ). The sodium currents underlying these action potentials were blocked by $0.1 \mu \mathrm{M}$ tetrodotoxin (TTX) and manifested a fast time course (Figure $8 \mathrm{c}$ ). Potassium and calcium channels were also detected (data not shown). After 3 weeks in culture, approximately $30 \%$ of the cells exhibited glutamate-evoked currents that could be partially blocked by D-APV, a specific antagonist of NMDA-type glutamate receptors (Figure 8d). In four cells, we observed robust $\gamma$-aminobutyric acid (GABA)evoked currents, indicating that these cells could respond to this inhibitory transmitter (Figure 8e). Miniature excitatory postsynaptic currents (mEPSCs), which reflect functional synaptic activity, were detected after 3 weeks of differentiation (Figure 8f). Taken together, these findings suggest that a proportion of the C-NPCs differentiated sufficiently to display a variety of electrophysiological properties typical of bona fide neurons.

C-NPCs survive, migrate, and differentiate on transplantation into the neonatal mouse brain. Human ESC-derived NPCs were transduced with a PGK-eGFP lentiviral cassette and transplanted into the lateral ventricles of newborn CD1 mice ( $\sim 10^{5}$ cells per animal). Ten weeks later, the animals were sacrificed and brain sections analyzed for the presence of cells expressing the eGFP marker. Many human eGFP-labeled cells were detected in various regions of the brain, including cells with morphologies characteristic of newly generated olfactory bulb granule neurons (Figure 9a-e). Cells with complex, branched morphologies and recognizable dendritic spines (characteristic of neuronal cells) were detected in the cortex (Figure $9 f$ and $i-n)$. Rare cells with round cell bodies and no processes were found in the SVZ and choroid plexus (Figure $9 g$ and $h$ ). Cell bodies in the cortex were often found in clusters (Figure $9 \mathrm{~m}$ and $\mathrm{n}$ ), probably due to additional rounds of division after transplantation. These results demonstrate that on transplantation into the mouse brain, C-NPCs can survive, migrate, and differentiate into cells with morphologies typical of neuronal cells types. To unequivocally prove the neuronal identity of these differentiated C-NPCs, we used immunocytochemistry with specific neuronal markers viewed under confocal microscopy (Figure 10). At 12 weeks after transplantation, many eGFP-expressing cells were found to be positive for the neuronal marker MAP2, consistent with the notion that these human C-NPCs had differentiated into neurons after transplantation (Figure 10a and $\mathrm{e}-\mathrm{g}$ ).

C-NPCs do not hyperproliferate or form tumors in vivo. Previous studies had shown that ESCs transplanted into SCID mice resulted in teratoma formation, ${ }^{8,39,40}$ and even transplantation of ESC-derived neural stem cells had resulted in neural cell hyperproliferation or frank malignancy. ${ }^{1,41}$ In contrast, in this study, none of the newborn mice injected with C-NPCs (ranging from $10^{5}$ to $10^{6}$ cells per animal) developed discernable brain tumors or neoplasia on examination of brain sections at 2-15 weeks after transplantation (20 mice analyzed over a 1-year period). Similarly, none of six adult mice injected intravenously with C-NPCs developed pathological overgrowth. Additionally, no teratomas were observed after intramuscular injection of $3 \times 10^{6}$ C-NPCs into SCID mice; injection of $1 \times 10^{6}$ ESCs produced teratomas as expected (data not shown). These results are consistent with complete loss of pluripotent phenotype in C-NPCs, which stain negatively for Oct4 and Nanog, and limited capacity for in vivo proliferation.

\section{Discussion}

Difference from previous neuralization protocols. Numerous protocols for neuralization of hESCs have been previously reported (representative examples are cited here). ${ }^{1,9,18,41}$ The major difference in our protocol is in the very first step of neuralization (the 'priming step'). In fact, our protocol does not use a priming step. Here, hESCs were dissociated into small clusters (50-100 cells), which were separated from single cells and debris, and immediately placed into defined medium supplemented with FGF2 and EGF. Also distinct from most published protocols, this study did not use feeder layers, serum, or serum replacement in the priming step. Indeed, most recent neuralization protocols initially grow hESCs for 4-6 days with serum, ${ }^{9,41}$ with $20 \%$ knockout serum replacement, ${ }^{18}$ or with feeder layers, ${ }^{1}$ such as MS5. As yet, NPCs have not been sufficiently characterized when generated from hESCs using serum-free and feeder layer-free priming steps. ${ }^{17}$

Our rapid neuralization process resulted in a limited proliferation capacity of C-NPCs (generally 5-6 passages), whereas previous work reported extensive proliferation of ESC-derived neural stem cells. ${ }^{1,41}$ In contrast, the use of knockout serum replacement by other workers has recently been linked to extensive in vitro proliferation of ESC-derived neural stem cells. ${ }^{42}$ Additionally, prior in vitro expanded, ESCderived stem cells were reported to form neoplastic or neural hyperproliferation when transplanted in vivo. ${ }^{1,41}$ Instead, we have seen no signs of hyperproliferation 2-6 months after transplantation of C-NPCs into newborn or adult mice. The limited in vitro expansion of C-NPCs in our study correlated with the absence of in vivo hyperproliferation, potentially due to a lack of oncogene expression in the C-NPCs, as further discussed below.

Transient genome expression stages during hESC neuralization and unique expression profile of C-NPCs. Analysis of whole-genome expression changes with multiple methods, including gene expression kinetics, unsupervised clustering, and WGCNA, showed that the earliest changes in gene expression occurred within 6-12 h of the induction of differentiation. This stage was followed by a latent period $(12-72 \mathrm{~h}$ ) with relatively few transcriptional alterations. Subsequently, two major waves of change in gene expression occurred at approximately 72 and $144 \mathrm{~h}$. The first wave of transcriptional change occurred before 


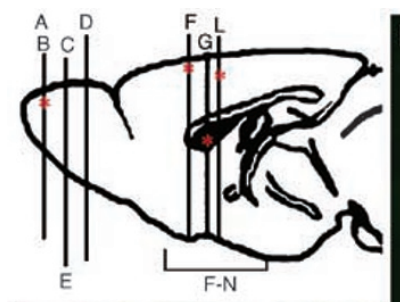

b
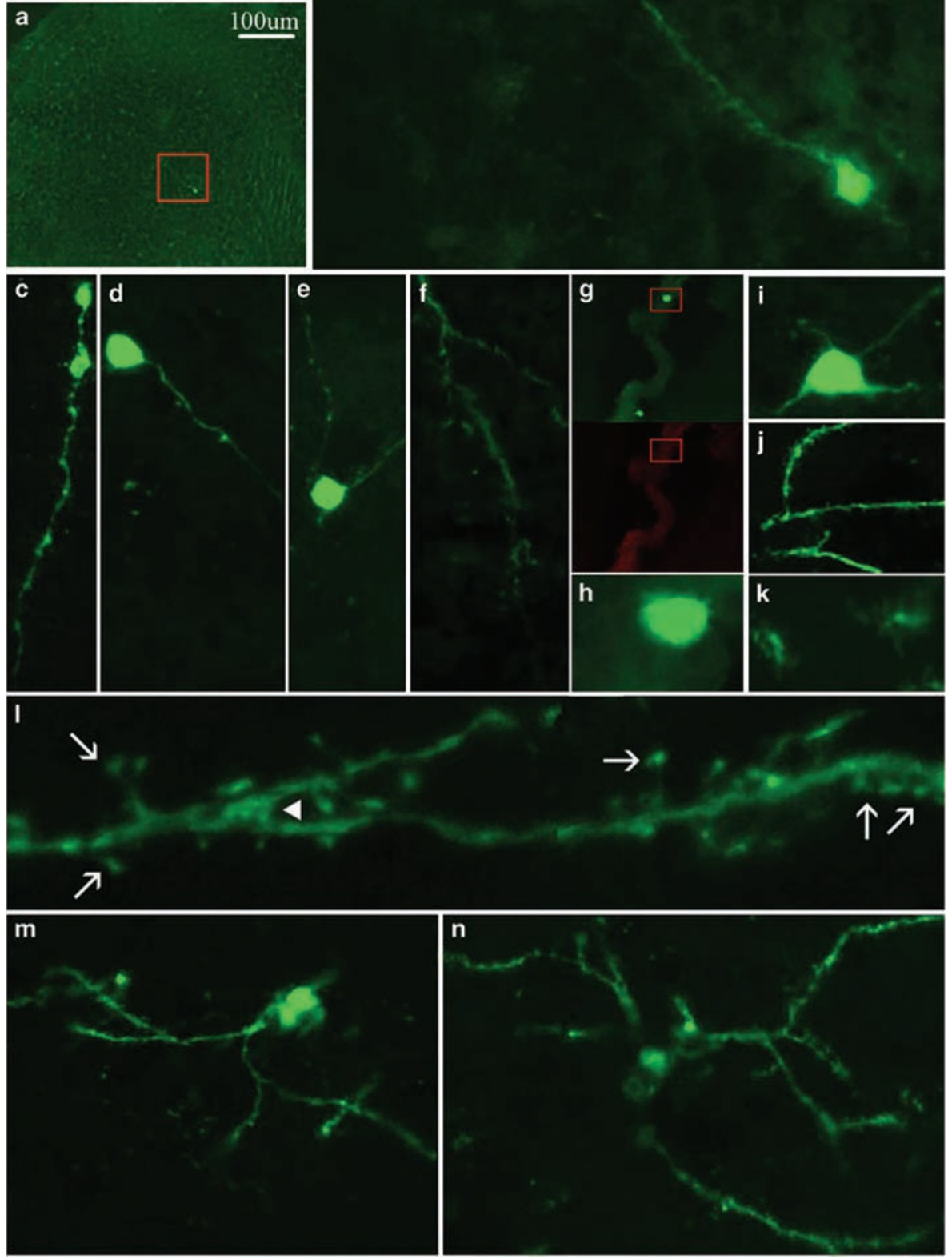

Figure 9 hESC-NPC transplantation into the neonatal mouse brain. hESC-NPCs engineered with a PhG-eGFP cassette were transplanted into the lateral ventricle of newborn CD1 mice $(n=6)$ and analyzed 10 weeks later. Upper left: camera lucida shows the position of $14 \mu \mathrm{m}$-thick coronal sections through the olfactory bulb (OB) and cortex (position of eGFP-positive cells indicated with red stars). (a-e) Sections through the OB. Note characteristic morphology of newly generated OB granule neurons. (f- $n$ ) Sections through the cerebral cortex adjacent to the lateral ventricles. A branched neuritic process detected at the periphery of the cortex (f). Round fluorescent cells without processes detected in the choroid plexus ( $\mathbf{g}$ and $\mathbf{h}$ ). (h) represents an enlargement of the red box in $(\mathbf{g})$; the field in $(\mathbf{g}$ )is shown under both green (upper) and red (lower) fluorescence channels to exclude autofluorescence. (i-n) Cells of various morphologies detected in the cortex. (I) Branching neuritic processes (arrowhead) and multiple dendritic spines (arrows) characteristic of mature neurons. ( $\mathbf{m}$ and $\mathbf{n}$ ) Clusters of transplanted cells with complex, branched morphology found in the right and left cortical hemisphere, respectively 

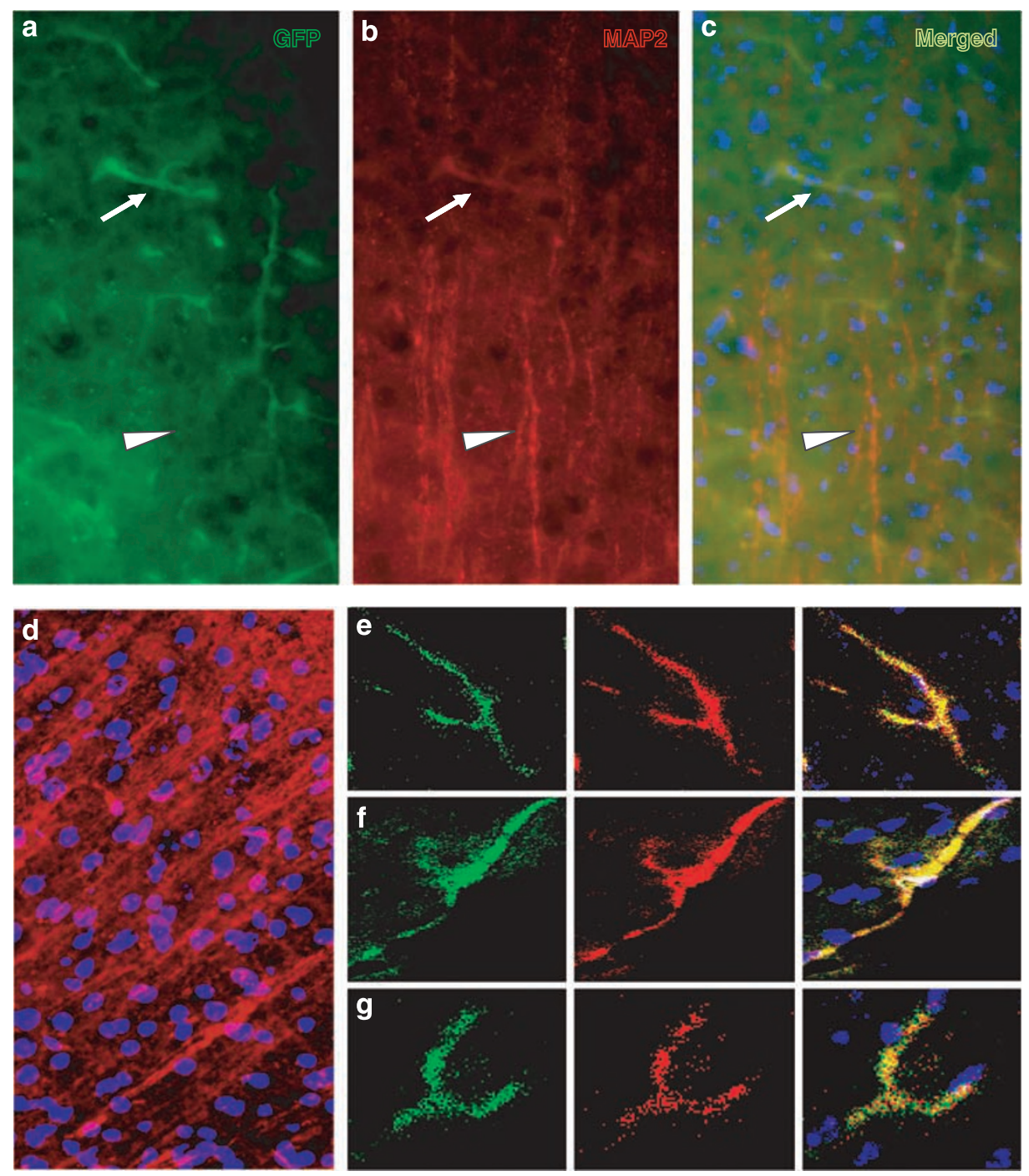

Figure 10 Immunostaining of mouse cortex following transplantation of C-NPCs. C-NPCs engineered with a PGK-eGFP cassette were transplanted into the lateral ventricle of newborn CD1 mice and analyzed after 12 weeks. (a-c) Colocalization of eGFP-positive, transplanted cells with the neuronal marker MAP2 (arrows). Note that host MAP2-positive cells do not colocalize with eGFP (arrowheads). (d) Endogenous MAP2 expression in the mouse cortex. (e-g) Confocal microscopy demonstrated colocalization of eGFP and MAP2 in several cells with branched morphology, consistent with neuronal differentiation of transplanted C-NPCs

the occurrence of the morphological change known as epithelial-like rosettes, which formed between 120 and $144 \mathrm{~h}$ after the start of differentiation. The first wave of change in gene expression coincided with the transient upregulation of transcripts encoding FGF5, a known marker of primitive ectoderm in mice. ${ }^{43}$ This and other transcripts observed during the first wave of change in gene expression are consistent with the early transition of these hESCs through the primitive ectoderm stage, as previously reported during mouse ESC neuralization. ${ }^{43,44}$ With our protocol, these changes occurred, however, much earlier than previously suggested for hESC neuralization. ${ }^{18}$ Other FGFs, such as FGF8 and FGF18, which were prominently upregulated during neuralization of mouse ESCs, remained unchanged (data not shown), suggesting that differences exist between mouse and human ESC differentiation. Metaanalysis of all available microarray data, using the NextBio engine, suggested that gene expression changes in the first wave were best correlated with known expression profiles previously observed during development, regionalization, and organ morphogenesis. In contrast, expression changes in the second wave were closely associated with more restricted expression profiles, as found during peripheral nervous system development, brain development, and neurogenesis.

Our meta-analysis of dynamic gene expression was complemented by a novel approach, WGCNA, which identifies modules of coexpressed genes corresponding to functional units. ${ }^{30,31}$ For each module, the WGCNA approach identified Hub genes, which encompass known genes as well as genes previously unknown to be involved in neuralization. This approach was validated by the identification of these genes in several canonical pathways previously reported to be involved in ESC neuralization. For instance, we 
detected upregulation of the $\mathrm{Wnt} / \beta$-catenin pathway, recently reported to be involved in ESC neuralization, ${ }^{32}$ upregulation of integrin and leukocyte extravasation signaling pathways, previously reported to be involved in neural precursor-mediated neuroprotection via immunomodulatory mechanisms, ${ }^{33}$ and upregulation of nicotinamide metabolism, found to be critical for efficient neuralization of ESCs (Cimadamore $\mathrm{F}$ et al., unpublished observations). The WGCNA approach identified nine functional modules and a number of Hub genes associated with each functional module. This analysis provides a list of novel candidate genes and pathways, which are likely to play a role in hESC neuralization.

Whole-genome comparisons suggested that C-NPCs share some features with recently described rosette-NSCs (R-NSCs). ${ }^{1}$ Indeed, genes such as DACH1, PLZF, NR2F1, LMO3, and LEF1 are shared by both C-NPCs and R-NSCs. CNPCs also lack expression of PMP2, HOP, AQP4, SPARCL1, and OLIG1 transcripts, which are found in NSCs conventionally propagated with FGF + EGF. Similar to R-NSCs, C-NPCs are capable of multilineage differentiation into various CNS cell types as well as neural crest fates (Curchoe $\mathrm{C}$ et al., unpublished observations). However, C-NPCs lack several markers possessed by R-NSCs such as PLAG1, ZNF312, LIX1, DMRT3, FAM70A, MMRN1, RSPO3 or EMX20X. In contrast to R-NSCs, C-NPCs have only a limited proliferation capacity in vitro and do not hyperproliferate or form tumors after transplantation into neonatal mice. Accordingly, R-NSCs, but not C-NPCs, express mRNA transcripts, such as PLAG1 or RSPO3 that have been previously described as potent oncogenes. ${ }^{45-47}$ This lack of oncogenic expression in C-NPCs might explain their limited amplification capacity and their lack of tumorigenicity in vivo.

Additionally, during hESC neuralization, we observed a robust upregulation of PAX6 and other genes known to play a role in development and maintenance of multipotent neural precursors in both the human and mouse systems. ${ }^{26,27}$ In the developing murine neocortex, expression of Pax6 was reported to precede that of Tbr2 (Eomes). ${ }^{48}$ In our studies, during hESC neuralization, we found that Tbr2 transcripts were transiently upregulated between days 2 and 5 , but completely downregulated by day 10 . Interestingly, in humans, disruption of Tbr2 has been implicated in a microcephaly syndrome of autosomal recessive inheritance, suggesting a role for Tbr2 in division and/ or migration of neural precursors. ${ }^{49}$ The absence of Tbr2 from proliferating hESC-derived NPCs in this study would favor such a role in migration.

Recently, Pankratz et al. ${ }^{18}$ described neural differentiation from ESCs via an obligate primitive anterior stage. The authors demonstrated the presence of forebrain regional markers (Otx2, Lhx2, Bf1) and the absence of the hindbrain marker HoxB4 in their neuroepithelial precursors. In contrast, we have observed both anterior markers (e.g., Emx2, Otx2, Pax2, Irx3, Pax6, DIx1/2) and posterior markers (HoxA2, HoxB2, HoxB4, HoxB6) during ESC neuralization with our protocol. Some of these markers were transiently upregulated (Pax2, Gbx2, HoxB6) or downregulated (Otx2) during neuralization. Although we did not add retinoic acid in our neuralization protocol, the B27 supplement used in our original protocol contained low levels of retinoic acid.
However, we subsequently obtained identical results using B27 supplement lacking retinoic acid or vitamin A (retinol). One potential explanation for the discrepancies between our findings and those of Pankratz et al. is that they used $20 \%$ knockout serum replacement for the first 4 days of neuralization, whereas in our protocol ESCs were placed into a serumfree neuralization medium.

Originally, work in Xenopus demonstrated the onset of rudimentary anterior-posterior identity in the primitive neural tube. ${ }^{50}$ Two hypotheses have been proposed to explain this phenomenon. The 'activation-transformation model' suggests that primitive neuroepithelium has anterior (forebrain) characteristics and that other signals (e.g., from the caudal structures) induce posterior neural fates (midbrain, hindbrain, and spinal cord). ${ }^{51}$ The 'multiple centers model' holds that distinct signals in the developing neural tube directly induce different anterior-posterior identities in neural tissue. ${ }^{52}$ Although the rapid neuralization of human ESCs described here does not seem to proceed via an obligate primitive anterior stage, ${ }^{18}$ the patterning signals present during early human neural tube development remain unknown. Further experiments are needed to determine which model of neuroectodermal specification explains the development of the human neural tube.

Efficient neuralization of ESCs occurs in the absence of exogenous Noggin. This study demonstrates that exogenous Noggin is dispensable for differentiation of ESCs into neural precursors that are uniformly positive for neuroectodermal markers but remain uniformly negative for undifferentiated markers, markers of other germ layers, and markers of mature neurons or glia. Previous reports described directed differentiation of ESCs into neural precursors using high concentrations (up to $700 \mathrm{ng}$ ) of Noggin, which presumably act to inhibit BMP2/4 activity in the cultures. ${ }^{13,14}$ Indeed, in the classical Xenopus model of neuroectodermal development, inhibition of BMP activity by Noggin was found to be critical for induction of neurogenesis. ${ }^{53}$ However, earlier studies in Xenopus documented that dissociation of primitive epidermis before gastrulation is sufficient to induce neural differentiation of epithelial cells. ${ }^{54}$ In the mouse, neural specification of ESCs may occur by a 'default mechanism' following growth-factor withdrawal resulting in neural precursor formation. ${ }^{55}$ The efficiency of this neuralization process can be improved with the addition of $N$-acetylcysteine (NAC) and CAMP. ${ }^{19}$ Nonetheless, in the absence of exogenous Noggin, cell-to-cell variation in gene expression may result in subtle differences within neural lineages. Both follistatin (a BMP inhibitor) and BMP5 are transiently upregulated at different time points during neuralization, suggesting that modulation of the TGF $\beta$ pathway may be important. The TGF $\beta / \mathrm{Smad}$ pathway can also be affected by local production of EGF and bFGF, in addition to that present in the growth media. These growth factors can lead to phosphorylation of the Smad1 linker region and inhibition of TGF $\beta$ signaling. ${ }^{56} \mathrm{~A}$ large body of evidence suggests a role of FGF signaling in neural induction in vivo in frog, chick, and planaria, and in vitro during mouse ESC differentiation. ${ }^{57-59}$ 
C-NPCs give rise to differentiated neuronal cells with functional channels in vitro and in vivo. Immunohistochemical, morphological, and physiological data demonstrate that the C-NPCs described in this work can give rise to functional neuronal cells both in vitro and in vivo. Several characteristic types of neuronal activity were recorded in vitro, suggesting that C-NPCs are capable of producing a broad spectrum of functional CNS neurons. Indeed, on transplantation into the lateral ventricle of newborn mice, these hESC-derived/eGFP-labeled cells were found in the olfactory bulb $(\mathrm{OB})$ and neocortex. The morphologies of these donor-derived eGFP-positive cells were characteristic of young neurons in the corresponding areas. For example, transplanted cells migrating to the OB manifest a single process typical of endogenous granule neurons, ${ }^{60}$ whereas those located in the cortex displayed a highly branched pattern with clearly identifiable dendritic spines as seen in cortical interneurons. ${ }^{61}$ Confocal imaging after immunostaining demonstrated colocalization of eGFP and MAP2 in many transplanted cells. These results suggest that transplanted C-NPCs can survive, migrate, and differentiate into cells manifesting the morphology and markers characteristic of resident neurons.

Conclusions. In summary, in this study we characterized molecular stages and pathways dynamically engaged during rapid and uniform neuralization of human ESCs. We also identified novel candidate genes (e.g., Hub genes) that may play previously unrecognized roles in ESC neuralization. We describe the robust and uniform derivation of committed neural precursor cells (C-NPCs), which are capable of differentiation into multiple lineages both in vitro and in vivo, most importantly, whereas avoiding hyperproliferation and tumor formation on transplantation into the mouse brain.

\section{Materials and Methods}

Cell cultures. Two $\mathrm{NIH}$-approved human ESC lines ( $\mathrm{H} 9$ and $\mathrm{H} 14)$ were used with equal success to generate homogeneous cultures of human neural precursors. $\mathrm{hESC}$ s were grown with MEF feeders in knockout DMEM-20\% serum replacement and $8 \mathrm{ng} / \mathrm{ml} \mathrm{bFGF}$. Spheroid body formation: Small clusters (50-100 cells) of ESCs were grown in polypropylene dishes (Ted Pella) in SM containing a 1:1 ratio of DMEM/F12-neurobasal medium with $\mathrm{N} 2+$ B27 supplements, $20 \mathrm{ng} / \mathrm{ml}$ insulin, $20 \mathrm{ng} / \mathrm{ml} \mathrm{bFGF}$, and $20 \mathrm{ng} / \mathrm{ml}$ EGF. The medium was changed every other day. Spheres were collected, gently triturated and plated on polyornithine-coated $(5 \mathrm{ng} /$ $\mathrm{ml}, 1 \mathrm{~h}$ at RT; Sigma) Corning plates in the NPC expansion medium (EM) containing a 1:1 ratio of DMEM/F12, $10 \%$ BIT 9500, $20 \mathrm{ng} / \mathrm{ml} \mathrm{bFGF,} 20 \mathrm{ng} / \mathrm{ml} \mathrm{EGF,} 5 \mu \mathrm{g} / \mathrm{ml}$ fibronectin, and $2 \mu \mathrm{g} / \mathrm{ml}$ heparin. For the BMP/Noggin experiment, $10 \mathrm{ng} / \mathrm{ml}$ of BMP2 and $10 \mathrm{ng} / \mathrm{ml}$ of BMP4 or, alternatively, $100 \mathrm{ng} / \mathrm{ml}$ of Noggin were added for the 5 days of neuralization ( $1 / 2$ medium change every day). In vitro differentiation: C-NPCs cells were plated on polyornithine + laminin-coated cover slips $(100 \mu \mathrm{g} / \mathrm{ml}$ polyornithine, $1 \mathrm{~h}$ at RT followed by $5 \mu \mathrm{g} / \mathrm{ml}$ laminin, $1 \mathrm{~h}$ at $37^{\circ} \mathrm{C}$ ) in differentiation medium and cultured for 1-3 weeks before fixation and antibody staining or for 3-5 weeks for electrophysiological studies. The differentiation medium contained a 1:1 ratio of DMEM/F12 with B27 supplement and $1 \%$ horse serum or a $3: 1$ ratio of DMEM/F12-neurobasal medium with B27 supplement containing $1 \%$ horse serum.

Immunocytochemistry. Cells were fixed with freshly prepared, ice-cold $4 \%$ PFA for $10 \mathrm{~min}$, washed in PBS, and blocked for $1 \mathrm{~h}$ in PBS, 5\% BSA, $0.1 \%$ Triton $X-100$. Cells were incubated with primary antibodies against OCT4, SOX2, NESTIN, MUSASHI, VIMENTIN, GFAP, 01, $\beta$ III-tubulin (TuJ1), MAP2, MBP, or NSE overnight at $4^{\circ} \mathrm{C} .01$ staining yielded similar results on nonpermeabilized cells (data not shown). All primary antibodies used in this study were from Chemicon/Millipore except anti-OCT4 (Santa Cruz) and anti-TuJ1 (Covance). Stained cells were mounted in AquaPoly/Mount (Polysciences).

RT/Q-PCR. Undifferentiated ESC clusters growing in SM for 6 days and NPCs grown for an additional 5-6 days in EM were collected and lysed in Trizol (Sigma) for RNA isolation. Total RNA $(2 \mu \mathrm{g})$ per sample was used for reverse transcription according to the manufacturer's specifications (Invitrogen). The RT product was diluted 10-fold before PCR amplification with gene-specific primers (see Supplementary Materials). For Q-PCR, total RNA was extracted using the RNeasy kit and reverse transcribed with the Quantitect kit (Qiagen) according to manufacturer's suggestions. Microarray and Q-PCR were processed by the Burnham Institute's gene analysis core facility. Signals were normalized to GAPDH.

Microarray analysis. RNA was isolated using Qiagen RNeasy columns. About $500 \mathrm{ng}$ total RNA per time point was used for cDNA synthesis followed by cRNA synthesis/amplification and labeling using the 'Illumina RNA amplification' kit (Ambion). The labeled cRNA was hybridized to Human WG-6 sentrix BeadChip Arrays (Illumina) and scanned following the manufacturer's instructions. Analysis was performed using algorithms included with GeneSpring software. To be considered significant, gene expression changes had to be greater than twofold with $P<0.05$ on parametric testing (Volcano statistical analysis)

Western blot analysis. Western blots were performed as described. ${ }^{62}$ Briefly, total cell protein was recovered in RIPA buffer, lysates separated by SDSPAGE, blotted onto PVDF membrane and sequentially probed with rabbit antiphospho-Smad1/5 (Cell Signaling no. 9516), mouse anti-actin (AC74; Sigma), and rabbit anti-Smad5 (Cell Signaling no. 9517) followed by secondary HRP-conjugated antibodies (Pierce).

Lentiviral transduction. A single-cell suspension of NPCs was prepared by incubation in $\mathrm{Ca}^{2+}$ - and $\mathrm{Mg}^{2+}$-free PBS for $15 \mathrm{~min}$. The cells were collected in $5 \mathrm{ml}$ polystyrene tubes and resuspended in $500 \mu \mathrm{l}$ of EM containing $5 \mu \mathrm{g} / \mathrm{ml}$ polybrene and second generation p156-RRL-sin18-PPT- $h P G K$-eGFP-PRE lentivirus at an $\mathrm{MOI}$ of 5 . The cells were incubated at $37^{\circ} \mathrm{C}, 5 \% \mathrm{CO}_{2}$ for $3 \mathrm{~h}$, and then washed with PBS before plating in EM on polyornithine-coated plates. Approximately $70 \%$ of the cells were GFP-positive $24 \mathrm{~h}$ after infection. For in vitro studies, $\mathrm{H} 9$ cells transduced with lentiviral vectors harboring tissue specific promoter-reporter cassettes were used (Oct4-GFP, Musashi1-eGFP, and MELK-eGFP).

Proteome profiling. Cells were washed with ice-cold PBS and lysed in Triton $X$ (TX)- 100 lysis buffer $(0.2 \%$ (w/v) TX-100, $20 \mathrm{mM}$ HEPES, $80 \mathrm{mM}$ $\beta$-glycerophosphate, $200 \mathrm{mM}$ EGTA, $15 \mathrm{mM} \mathrm{MgCl}, 1 \mathrm{mM} \mathrm{Na}_{3} \mathrm{VO}_{4}, 1 \mathrm{mM}$ phenylmethyl sulfonyl fluoride, $10 \mu \mathrm{g}$ aprotinin, $10 \mathrm{mg} / \mathrm{ml}$ leupeptin $(\mathrm{pH} 7.4))$ in the presence of protease inhibitors (Roche Biochemicals). About $4 \times 10^{6}$ cells were lysed on ice for 30-210 $\mathrm{min}$ and then sonicated with five $4 \mathrm{~s}$ pulses on ice. The solution was centrifuged ( $14000 \times g$ at $4^{\circ} \mathrm{C}$ for $10 \mathrm{~min}$ ), the supernatant recovered, and aliquots stored at $-80^{\circ} \mathrm{C}$ until analysis. The cell lysates were quickly thawed and proteins denatured by addition of 4 volumes of $9.5 \mathrm{M}$ urea $+2 \%$ CHAPS for $10 \mathrm{~min}$ at room temperature. Thereafter, the mixtures were centrifuged to remove insoluble protein. After centrifugation ( $10 \mathrm{~min}$ at $14000 \times \mathrm{g})$, the supernatant $(2.5$, 5 , or $25 \mu \mathrm{l}$, equal to 1,2 , or $4 \mu \mathrm{g}$ total cell protein, respectively) was mixed with $150 \mu \mathrm{l}$ of a $10 \mathrm{mM}$ ammonium acetate solution (pH 6) containing $0.1 \%$ TX-100, incubated on a ProteinChip (WCX2) in a bioprocessor (Ciphergen Biosystems Inc.), and shaken for $30 \mathrm{~min}$ at 550 r.p.m. The protein chips were then washed three times with the ammonium acetate solution followed by three additional washes in double-distilled water. After air drying, saturated sinapinic acid in $50 \%$ acetonitrile/ $0.5 \%$ trifluoroacetic acid was applied to the matrix twice using $1 \mu \mathrm{l}$ per spot. The airdried chip was read in a Ciphergen PBSII ProteinChip reader with laser intensities set at 220, 240, or $260 \mathrm{~nm}$ and the detector sensitivity set to 9 . The raw spectra were processed using ProteinChip Software, version 3.1 (Ciphergen Biosystems Inc.).

C-NPC transplantation. Under cryoanesthesia, newborn ICR-CD1 pups were injected into the left ventricle with $1 \times 10^{5} \mathrm{GFP}$-lentinfected NPCs. All the pups developed normally and no tumors were detected. The animals were sacrificed at 10 or 12 weeks. The heart was exposed and perfused with $30 \mathrm{ml}$ of heparinized PBS followed by $30 \mathrm{ml}$ of ice-cold $4 \%$ paraformaldehyde. The brain was dissected and fixed in 4\% PFA overnight, washed in PBS, and saturated with $25 \%$ sucrose for $24 \mathrm{~h}$ before freezing in OCT. We then cut $14 \mu \mathrm{m}$-thick cryosections and analyzed them 
for cells expressing the GFP marker. Counter-staining with anti-GFP antibody was performed as described above.

Calcium imaging. Measurement of intracellular free $\mathrm{Ca}^{2+}\left(\left[\mathrm{Ca}^{2+}\right] \mathrm{i}\right)$ in differentiated human NSC cultures was performed using Fura-2/AM or Fluo-3/AM as described previously, ${ }^{63}$ with minor modifications. Briefly, hESC-derived NPCs were washed twice with recording medium containing $150 \mathrm{mM} \mathrm{NaCl}, 3 \mathrm{mM} \mathrm{KCl}$, $2 \mathrm{mM} \mathrm{CaCl} 2,5 \mathrm{mM}$ glucose, $10 \mu \mathrm{M}$ glycine, and $10 \mathrm{mM}$ HEPES (pH 7.4), and incubated at $37^{\circ} \mathrm{C}$ in recording medium containing $30 \mathrm{nM}$ Pluronic $\mathrm{F}-127$ and $5 \mu \mathrm{M}$ Fluo-3/AM for $30 \mathrm{~min}$ or $10 \mu \mathrm{M}$ Fura-2/AM for $60 \mathrm{~min}$ (acetoxymethyl esters; Molecular Probes). Cultures were then washed three times with recording medium and allowed to settle at $37^{\circ} \mathrm{C}$ for at least $30 \mathrm{~min}$. Cells were used within $1 \mathrm{~h}$. During the experiments, cells were kept in a superfusion chamber on the microscope stage at RT (for Fluo-3) or $37^{\circ} \mathrm{C}$ (for Fura-2 experiments). Imaging was performed using a Sutter DG-4 fast wavelength switcher coupled to a Zeiss Axiovert microscope with a 20X, 0.5 NA, objective. Digital images were acquired every $500 \mathrm{~ms}$ with a cooled CCD camera (Cooke Sensicam, PCO, Germany) controlled by SlideBook software (Intelligent Imaging Innovations, Santa Monica, CA, USA). Changes in intensity were calculated by dividing the measured fluorescence intensity $(F$; ratio of $340 / 380 \mathrm{~nm}$ for Fura-2) by the measured average baseline fluorescence intensity $\left(F / F_{0}\right)$. Excitation was achieved using standard FITC or Fura-2 filter sets (Chroma Technologies)

Electrophysiological recordings. Cultured C-NPCs, plated on polyornithine $(5 \mathrm{ng} / \mathrm{ml})$-coated $12 \mathrm{~mm}$ glass cover slips were placed in a recording chamber having a volume of $\sim 150 \mu \mathrm{l}$. The recording chamber was mounted on the stage of a Zeiss Axiovert inverted microscope. The whole-cell configuration of the patch-clamp technique was used for recording macroscopic currents at RT $\left(22 \pm 1^{\circ} \mathrm{C}\right.$ ). Signals were amplified using an Axopatch 200B amplifier (Axon Instruments) and filtered at $2 \mathrm{kHz}$ via a Bessel low-pass filter. The data were sampled and analyzed using pClamp9 software (Axon Instruments, USA) and a Dell computer Pentium III in conjunction with a DigiData interface (1322A; Axon Instruments). Patch pipettes were pulled from standard wall glass of $1.5 \mathrm{~mm} O D$ (Warner) and had a resistance of 7-10 M $\Omega$ when filled with intracellular solution. For recording voltage-gated currents, the following intracellular solution was used (in $\mathrm{mM}): 140 \mathrm{~K}$-gluconate; $5 \mathrm{NaCl}, 1 \mathrm{MgCl}_{2}, 10 \mathrm{EGTA}, 10$ HEPES, pH adjusted by KOH to 7.25 , osmolarity $290 \mathrm{mOsm}$. For recording ligand-gated currents, we used the following intracellular solution (in mM): 130 Cs-gluconate; $2 \mathrm{MgATP}, 1 \mathrm{MgCl}_{2} ; 10$ EGTA; 10 HEPES, pH adjusted by $\mathrm{CsOH}$ to 7.25 , osmolarity adjusted to $300 \mathrm{mOsm}$ with sucrose. The bath solution generally contained a $\mathrm{Na}^{+}$saline based on Hanks' balanced salt solution (in mM): $137 \mathrm{NaCl}, 1 \mathrm{NaHCO}_{3}, 0.34 \mathrm{Na}_{2} \mathrm{HPO}_{4}, 2.5 \mathrm{KCl}, 0.44$ $\mathrm{KH}_{2} \mathrm{PO}_{4}, 2.5 \mathrm{CaCl}_{2}, 0.5 \mathrm{MgSO}_{4}, 0.5 \mathrm{MgCl}_{2}, 5 \mathrm{HEPES}, 22.2$ glucose, $\mathrm{pH}$ adjusted to 7.3 by $\mathrm{NaOH}$. To elicit voltage-gated currents, step potentials were applied from -60 to $+30 \mathrm{mV}$ at $10 \mathrm{mV}$ intervals (duration of each step, $100 \mathrm{~ms}$ ). Each step was elicited after hyperpolarization to $-90 \mathrm{mV}$ for $300 \mathrm{~ms}$. Solutions of agonists and antagonists for various receptors were prepared in the bath solution and applied by an array of tubes placed 50-75 $\mu \mathrm{m}$ from the cells. Solution changes were achieved rapidly, within $50-100 \mathrm{~ms}$, by moving the array of continuous-flow pipettes relative to the cell with a micromanipulator driver. A control pipette containing bath solution was used to rapidly wash off applied drugs. Most compounds used (including NMDA, glycine, D-APV, TTX) were purchased from Tocris; GABA was purchased from Sigma.

Acknowledgements. We thank Dr. Phillip Schwartz for providing human fetal brain-derived NPCs for comparison and Dr. Satyajit K Mitra for helping with the Smad phosphorylation analysis. We thank Roy Williams for help with data analysis and the Burnham Institute for Medical Research Core Microarray Facility for excellent technical assistance. We thank Dr. Carol Curchoe for discussions. This work was supported by BIMR funds to AVT, by NIH Grant R01 NS050621 to MK, and a CIRM Comprehensive Grant to SAL and AVT. In addition, RB was partially supported by a CIRM postdoctoral fellowship. The support facilities of the La Jolla Interdisciplinary Neuroscience Center Cores (NIH Blueprint Grant P30 NS057096) is gratefully acknowledged.

1. Elkabetz Y, Panagiotakos G, Al Shamy G, Socci ND, Tabar V, Studer L. Human ES cellderived neural rosettes reveal a functionally distinct early neural stem cell stage. Genes Dev 2008; 22: 152-165.
2. Flax JD, Aurora S, Yang C, Simonin C, Wills AM, Billinghurst LL et al. Engraftable human neural stem cells respond to developmental cues, replace neurons, and express foreign genes. Nat Biotechnol 1998; 16: 1033-1039.

3. Tamaki S, Eckert K, He D, Sutton R, Doshe M, Jain G et al. Engraftment of sorted/ expanded human central nervous system stem cells from fetal brain. J Neurosci Res 2002 69: 976-986.

4. Lindvall O, Kokaia Z, Martinez-Serrano A. Stem cell therapy for human neurodegenerative disorders-how to make it work. Nat Med 2004; 10 Suppl: S42-S50.

5. Schwartz PH, Bryant PJ, Fuja TJ, Su H, O'Dowd DK, Klassen H. Isolation and characterization of neural progenitor cells from post-mortem human cortex. J Neurosci Res 2003; 74: 838-851.

6. Cadwell RC, Joyce GF. Randomization of genes by PCR mutagenesis. PCR Methods Appl 1992; 2: 28-33.

7. Chandran S, Compston A, Jauniaux E, Gilson J, Blakemore W, Svendsen C. Differential generation of oligodendrocytes from human and rodent embryonic spinal cord neural precursors. Glia 2004; 47: 314-324.

8. Thomson JA, Itskovitz-Eldor J, Shapiro SS, Waknitz MA, Swiergiel JJ, Marshall VS et al. Embryonic stem cell lines derived from human blastocysts. Science 1998; 282: 1145-1147.

9. Zhang SC, Wernig M, Duncan ID, Brustle O, Thomson JA. In vitro differentiation of transplantable neural precursors from human embryonic stem cells. Nat Biotechnol 2001; 19: $1129-1133$

10. Reubinoff BE, Itsykson $P$, Turetsky $T$, Pera MF, Reinhartz E, Itzik $A$ et al. Neura progenitors from human embryonic stem cells. Nat Biotechnol 2001; 19: 1134-1140.

11. Carpenter MK, Inokuma MS, Denham J, Mujtaba T, Chiu CP, Rao MS. Enrichment of neurons and neural precursors from human embryonic stem cells. Exp Neurol 2001; 172. 383-397.

12. Itsykson P, llouz N, Turetsky T, Goldstein RS, Pera MF, Fishbein I et al. Derivation of neural precursors from human embryonic stem cells in the presence of noggin. $\mathrm{Mol} \mathrm{Cell}$ Neurosci 2005; 30: 24-36.

13. Gerrard L, Rodgers L, Cui W. Differentiation of human embryonic stem cells to neura lineages in adherent culture by blocking bone morphogenetic protein signaling. Stem Cells 2005; 23: 1234-1241.

14. Yao S, Chen S, Clark J, Hao E, Beattie GM, Hayek A et al. Long-term self-renewal and directed differentiation of human embryonic stem cells in chemically defined conditions. Proc Natl Acad Sci USA 2006; 103: 6907-6912.

15. Watanabe K, Ueno M, Kamiya D, Nishiyama A, Matsumura M, Wataya T et al. A ROCK inhibitor permits survival of dissociated human embryonic stem cells. Nat Biotechnol 2007 25: 681-686

16. Conti L, Pollard SM, Gorba T, Reitano E, Toselli M, Biella G et al. Niche-independent symmetrical self-renewal of a mammalian tissue stem cell. PLoS Biol 2005; 3: e283.

17. Joannides AJ, Fiore-Heriche $C$, Battersby AA, Athauda-Arachchi $P$, Bouhon IA, Williams L et al. A scaleable and defined system for generating neural stem cells from human embryonic stem cells. Stem Cells 2007; 25: 731-737.

18. Pankratz MT, Li XJ, Lavaute TM, Lyons EA, Chen X, Zhang SC. Directed neural differentiation of human embryonic stem cells via an obligated primitive anterior stage. Stem Cells 2007; 25: 1511-1520.

19. Smukler SR, Runciman SB, Xu S, van der Kooy D. Embryonic stem cells assume a primitive neural stem cell fate in the absence of extrinsic influences. J Cell Biol 2006; 172 79-90.

20. Mitalipova MM, Rao RR, Hoyer DM, Johnson JA, Meisner LF, Jones KL et al. Preserving the genetic integrity of human embryonic stem cells. Nat Biotechnol 2005; 23: 19-20.

21. Joannides A, Fiore-Heriche C, Westmore K, Caldwell M, Compston A, Allen N et al. Automated mechanical passaging: a novel and efficient method for human embryonic stem cell expansion. Stem Cells 2006; 24: 230-235

22. Palmer TD, Schwartz PH, Taupin P, Kaspar B, Stein SA, Gage FH. Cell culture. Progenitor cells from human brain after death. Nature 2001; 411: 42-43

23. Bibel M, Richter J, Schrenk K, Tucker KL, Staiger V, Korte M et al. Differentiation of mouse embryonic stem cells into a defined neuronal lineage. Nat Neurosci 2004; 7: 1003-1009.

24. Pelton TA, Sharma S, Schulz TC, Rathjen J, Rathjen PD. Transient pluripotent cell populations during primitive ectoderm formation: correlation of in vivo and in vitro pluripotent cell development. J Cell Sci 2002; 115 (Pt 2): 329-339.

25. Mikkelsen TS, Ku M, Jaffe DB, Issac B, Lieberman E, Giannoukos G et al. Genome-wide maps of chromatin state in pluripotent and lineage-committed cells. Nature 2007; 448: 553-560.

26. Haubst N, Berger J, Radjendirane V, Graw J, Favor J, Saunders GF et al. Molecular dissection of Pax6 function: the specific roles of the paired domain and homeodomain in brain development. Development 2004; 131: 6131-6140.

27. Plachta N, Bibel M, Tucker $\mathrm{KL}$, Barde YA. Developmental potential of defined neural progenitors derived from mouse embryonic stem cells. Development 2004; 131 : 5449-5456.

28. Cheung M, Briscoe J. Neural crest development is regulated by the transcription factor Sox9. Development 2003; 130: 5681-5693.

29. Marin $\mathrm{O}$, Anderson SA, Rubenstein $\mathrm{JL}$. Origin and molecular specification of striata interneurons. J Neurosci 2000; 20: 6063-6076.

30. Oldham MC, Horvath S, Geschwind DH. Conservation and evolution of gene coexpression networks in human and chimpanzee brains. Proc Natl Acad Sci USA 2006; 103 17973-17978. 
31. Horvath S, Zhang B, Carlson M, Lu KV, Zhu S, Felciano RM et al. Analysis of oncogenic signaling networks in glioblastoma identifies ASPM as a molecular target. Proc Natl Acad Sci USA 2006; 103: 17402-17407.

32. Davidson KC, Jamshidi P, Daly R, Hearn MT, Pera MF, Dottori M. Wnt3a regulates survival, expansion, and maintenance of neural progenitors derived from human embryonic stem cells. Mol Cell Neurosci 2007; 36: 408-415.

33. Pluchino S, Zanotti L, Rossi B, Brambilla E, Ottoboni L, Salani G et al. Neurospherederived multipotent precursors promote neuroprotection by an immunomodulatory mechanism. Nature 2005; 436: 266-271.

34. Karsten SL, Kudo LC, Jackson R, Sabatti C, Kornblum HI, Geschwind DH. Global analysis of gene expression in neural progenitors reveals specific cell-cycle, signaling, and metabolic networks. Dev Biol 2003; 261: 165-182.

35. Dougherty JD, Garcia AD, Nakano I, Livingstone M, Norris B, Polakiewicz R et al. PBK TOPK, a proliferating neural progenitor-specific mitogen-activated protein kinase kinase. J Neurosci 2005; 25: 10773-10785.

36. Bi W, Yan J, Shi X, Yuva-Paylor LA, Antalffy BA, Goldman A et al. Rai1 deficiency in mice causes learning impairment and motor dysfunction, whereas Rai1 heterozygous mice display minimal behavioral phenotypes. Hum Mol Genet 2007; 16: 1802-1813.

37. Scheiermann C, Meda P, Aurrand-Lions M, Madani R, Yiangou $\mathrm{Y}$, Coffey $\mathrm{P}$ et al. Expression and function of junctional adhesion molecule-C in myelinated peripheral nerves. Science 2007; 318: 1472-1475.

38. Garcia AD, Doan NB, Imura T, Bush TG, Sofroniew MV. GFAP-expressing progenitors are the principal source of constitutive neurogenesis in adult mouse forebrain. Nat Neurosci 2004; 7: 1233-1241.

39. Amit M, Carpenter MK, Inokuma MS, Chiu CP, Harris CP, Waknitz MA et al. Clonally derived human embryonic stem cell lines maintain pluripotency and proliferative potential for prolonged periods of culture. Dev Biol 2000; 227: 271-278.

40. Xu C, Inokuma MS, Denham J, Golds K, Kundu P, Gold JD et al. Feeder-free growth of undifferentiated human embryonic stem cells. Nat Biotechnol 2001; 19: 971-974.

41. Roy NS, Cleren C, Singh SK, Yang L, Beal MF, Goldman SA. Functional engraftment of human ES cell-derived dopaminergic neurons enriched by coculture with telomeraseimmortalized midbrain astrocytes. Nat Med 2006; 12: 1259-1268.

42. Dhara SK, Hasneen K, Machacek DW, Boyd NL, Rao RR, Stice SL. Human neura progenitor cells derived from embryonic stem cells in feeder-free cultures. Differentiation 2008; 76: 454-464.

43. Rathjen J, Lake JA, Bettess MD, Washington JM, Chapman G, Rathjen PD. Formation of primitive ectoderm like cell population, EPL cells, from ES cells in response to biologically derived factors. J Cell Sci 1999; 112 (Pt 5): 601-612.

44. Aiba K, Sharov AA, Carter MG, Foroni C, Vescovi AL, Ko MS. Defining a developmental path to neural fate by global expression profiling of mouse embryonic stem cells and adult neural stem/progenitor cells. Stem Cells 2006; 24: 889-895.

45. Van Dyck F, Declercq J, Braem CV, Van de Ven WJ. PLAG1, the prototype of the PLAG gene family: versatility in tumour development (review). Int J Oncol 2007; 30 765-774.
46. Theodorou V, Kimm MA, Boer M, Wessels L, Theelen W, Jonkers J et al. MMTV insertional mutagenesis identifies genes, gene families and pathways involved in mammary cancer. Nat Genet 2007; 39: 759-769.

47. Wieser R. The oncogene and developmental regulator EVI1: expression, biochemical properties, and biological functions. Gene 2007; 396: 346-357.

48. Englund C, Fink A, Lau C, Pham D, Daza RA, Bulfone A et al. Pax6, Tbr2, and Tbr1 are expressed sequentially by radial glia, intermediate progenitor cells, and postmitotic neurons in developing neocortex. J Neurosci 2005; 25: 247-251.

49. Baala L, Briault S, Etchevers HC, Laumonnier F, Natiq A, Amiel J et al. Homozygous silencing of T-box transcription factor EOMES leads to microcephaly with polymicrogyria and corpus callosum agenesis. Nat Genet 2007; 39: 454-456.

50. Hamburger V. Ontogeny of neuroembryology. J Neurosci 1988; 8: 3535-3540.

51. Nieuwkoop PD. Inductive interactions in early amphibian development and their general nature. J Embryol Exp Morphol 1985; 89 (Suppl): 333-347.

52. Stern CD. Neural induction: old problem, new findings, yet more questions. Development 2005; 132: 2007-2021.

53. Hemmati-Brivanlou A, Melton DA A truncated activin receptor inhibits mesoderm induction and formation of axial structures in Xenopus embryos. Nature 1992; 359: 609-614.

54. Grunz H, Tacke L. Neural differentiation of Xenopus laevis ectoderm takes place after disaggregation and delayed reaggregation without inducer. Cell Differ Dev 1989; 28: 211-217.

55. Tropepe V, Hitoshi S, Sirard C, Mak TW, Rossant J, van Der KD. Direct neural fate specification from embryonic stem cells: a primitive mammalian neural stem cell stage acquired through a default mechanism. Neuron 2001; 30: 65-78.

56. Pera EM, Ikeda A, Eivers E, De Robertis EM. Integration of IGF, FGF, and anti-BMP signals via Smad1 phosphorylation in neural induction. Genes Dev 2003; 17: 3023-3028.

57. Streit A, Berliner AJ, Papanayotou C, Sirulnik A, Stern CD. Initiation of neural induction by FGF signalling before gastrulation. Nature 2000; 406: 74-78.

58. Cebria F, Kobayashi $\mathrm{C}$, Umesono $\mathrm{Y}$, Nakazawa M, Mineta K, lkeo K et al. FGFR-related gene nou-darake restricts brain tissues to the head region of planarians. Nature 2002; 419: 620-624.

59. Delaune E, Lemaire $P$, Kodjabachian L. Neural induction in Xenopus requires early FGF signalling in addition to BMP inhibition. Development 2005; 132: 299-310.

60. Petreanu L, Alvarez-Buylla A. Maturation and death of adult-born olfactory bulb granule neurons: role of olfaction. J Neurosci 2002; 22: 6106-6113.

61. Markram H, Toledo-Rodriguez M, Wang Y, Gupta A, Silberberg G, Wu C. Interneurons of the neocortical inhibitory system. Nat Rev Neurosci 2004; 5: 793-807.

62. Schlaepfer DD, Hunter T. Evidence for in vivo phosphorylation of the Grb2 SH2-domain binding site on focal adhesion kinase by Src-family protein-tyrosine kinases. Mol Cell Biol 1996; 16: 5623-5633.

63. Tenneti L, D'Emilia DM, Troy CM, Lipton SA. Role of caspases in N-methyl-D-aspartateinduced apoptosis in cerebrocortical neurons. J Neurochem 1998; 71: 946-959.

Supplementary Information accompanies the paper on Cell Death and Differentiation website (http://www.nature.com/cdd) 